\title{
Plutonium Discharge Rates and Spent Nuclear Fuel Inventory Estimates for Nuclear Reactors Worldwide
}

Brian K. Castle

Shauna A. Hoiland

Richard A. Rankin

James W. Sterbentz

September 2012

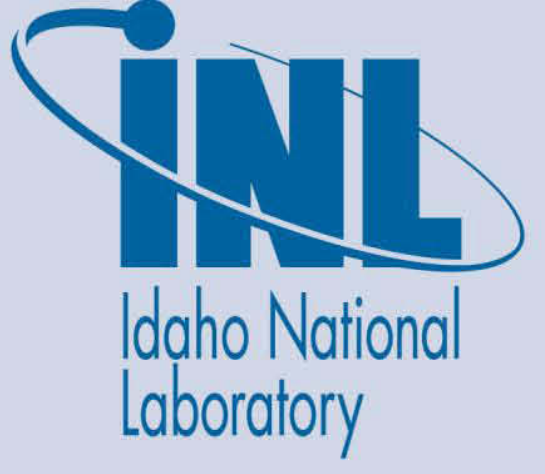

The INL is a U.S. Department of Energy National Laboratory operated by Battelle Energy Alliance 


\section{DISCLAIMER}

This information was prepared as an account of work sponsored by an agency of the U.S. Government. Neither the U.S. Government nor any agency thereof, nor any of their employees, makes any warranty, expressed or implied, or assumes any legal liability or responsibility for the accuracy, completeness, or usefulness, of any information, apparatus, product, or process disclosed, or represents that its use would not infringe privately owned rights. References herein to any specific commercial product, process, or service by trade name, trade mark, manufacturer, or otherwise, does not necessarily constitute or imply its endorsement, recommendation, or favoring by the U.S. Government or any agency thereof. The views and opinions of authors expressed herein do not necessarily state or reflect those of the U.S. Government or any agency thereof. 
INL/EXT-12-27150

\title{
Plutonium Discharge Rates and Spent Nuclear Fuel Inventory Estimates for Nuclear Reactors Worldwide
}

\author{
Brian K. Castle \\ Shauna A. Hoiland \\ Richard A. Rankin \\ James W. Sterbentz
}

September 2012

Idaho National Laboratory

Idaho Falls, Idaho 83415

http://www.inl.gov

Prepared for the

U.S. Department of Energy

Office of National Nuclear Security Administration

Under DOE Idaho Operations Office

Contract DE-AC07-05ID14517 



\begin{abstract}
This report is a preliminary survey and analysis of the five primary types of commercial nuclear power reactors currently in use around the world today. Annual plutonium discharge rates from these reactors are estimated based on a simple methodology that uses limited but readily available spent fuel burnup data and reactor operating characteristics collected from a several nuclear reactor databases. Selected commercial reactor operating and nuclear core characteristics are also presented for each reactor type.

In addition to the commercial reactor survey, a materials test reactor survey was also conducted to identify reactors of this general type with core power ratings $>1.0 \mathrm{MW}$. Over 100 material test reactors and research reactors fall into this category. Fuel characteristics and associated quantities of spent fuel from these reactors are also provided herein.
\end{abstract}




\section{CONTENTS}

ABSTRACT

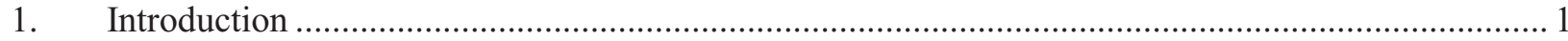

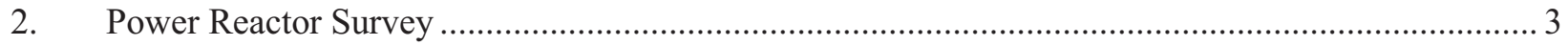

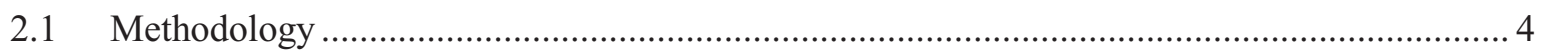

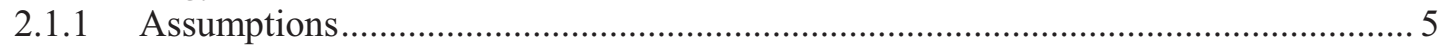

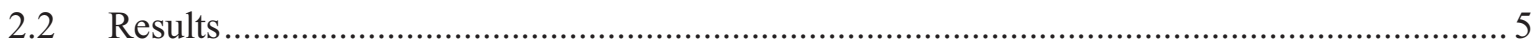

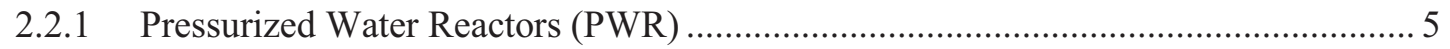

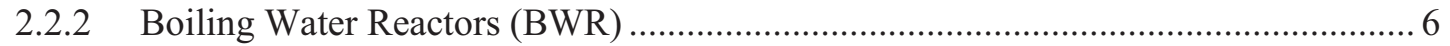

2.2.3 Pressurized Heavy Water Reactors (PHWR) ........................................................ 7

2.2.4 Reaktory Bolshoi Moschchnosti Kanalny (RBMK) .............................................. 8

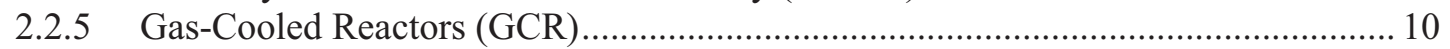

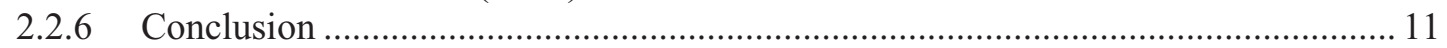

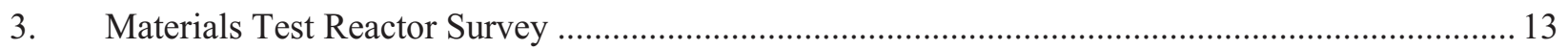

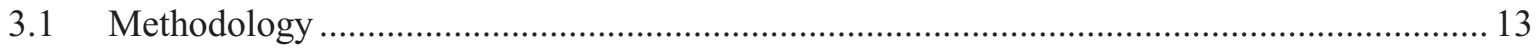

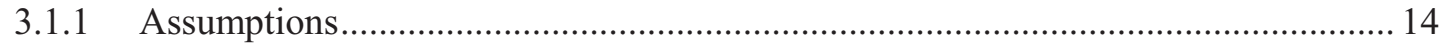

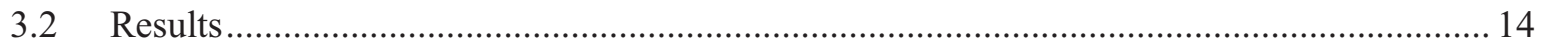

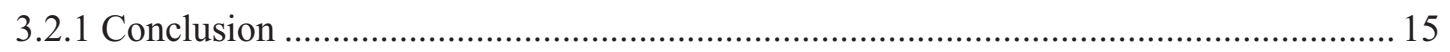

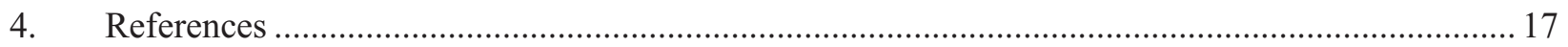

Appendix A Methodology to Estimate EOC Reactor Isotopic Plutonium Discharge Mass ..................... A-1

Appendix B High Power Research Reactors with Materials Test Capabilities .................................... B-1

Appendix C Distribution of Research Reactor Spent Fuel by Origin, Region, Enrichment and

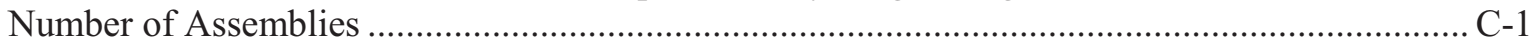

Appendix D Estimates of Aluminum-Based and TRIGA Irradiated Fuel Inventories - U.S. Origin....... D-1

\section{TABLES}

Table 1. Commercial reactors by type, country, and number. .............................................................. 3

Table 2. Typical PWR characterization data [3] [4] [6] .................................................................... 6

Table 3. PWR isotopic mass fractions and plutonium mass production rates. ......................................... 6

Table 4. Typical BWR characterization data [2] [3] [5] ................................................................... 7

Table 5. BWR isotopic mass fractions and plutonium mass production rates.......................................... 7

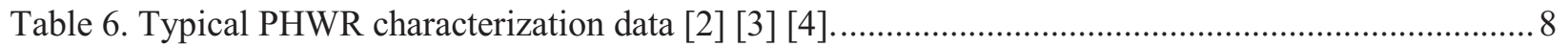

Table 7. PHWR isotopic mass fractions and plutonium mass production rates. ....................................... 8

Table 8. Typical RBMK characterization data [4] [5] [6] ...............................................................

Table 9. RBMK isotopic mass fractions and plutonium mass production rates. ...................................... 9 
Table 10. Typical GCR characterization data [4] [8] [9] [10] [11] .................................................. 10

Table 11. GCR isotopic mass fractions and plutonium mass production rates....................................... 10

Table 12. Annual plutonium mass discharge rates by reactor type..................................................... 11

Table C-1. Research reactor distribution by region, enrichment, and number of assemblies.................. C-1

Table D-1. Estimates of Irradiated Fuel Inventories of Foreign and Research and Test Reactors using Aluminum-based and TRIGA Fuels Containing Uranium of USA origin as of 2001 


\section{ACRONYMS/ABBREVIATIONS}

AGR advanced gas-cooled reactor

BOC beginning-of-cycle

BWR boiling water reactor

CANDU Canada deuterium uranium reactor

DOE U.S. Department of Energy

EOC end-of-cycle

GCR gas-cooled reactor

HEU high-enriched uranium

IAEA International Atomic Energy Agency

$\mathrm{kgU} \quad$ kilogram initial heavy metal uranium

LEU low-enriched uranium

LWR light water reactor

MF mass fraction

MT metric ton (1,000 kilograms)

MTR materials test reactor

MWd megawatt-day

MWe megawatt-electric

MWth megawatt-thermal

MTU metric tons of initial heavy metal uranium

PHWR pressurized heavy water reactor

PWR pressurized water reactor

RBMK reaktory bolshoi moschchnosti kanalny

SNF spent nuclear fuel

TRIGA Training, Research, and Isotopes General Atomics

VVER vodo-vodyanoi energetichesky reactor

WWER water-water power reactor 


\section{Plutonium Discharge Rates and Spent Nuclear Fuel Inventory Estimates for Nuclear Reactors Worldwide}

\section{Introduction}

All spent nuclear fuel (SNF) can be considered a potential proliferation and security risk. Highenriched fuels remain high-enriched even after burnup. Low-enriched fuels breed plutonium. All spent fuels contain radioactive fission products which, if dispersed, can produce an environmental and health disaster. Whether the threat comes from illicit procurement for nuclear weapons or radiological dispersion devices, spent nuclear fuel needs to be inventoried, stored securely, and routinely monitored.

Typically, the larger the stored inventory the greater the security risk, but even small vulnerable inventories can present major cause for alarm. Nuclear reactors, the sole producers of spent nuclear fuel, are located throughout the world and come in a variety of designs and sizes (core power rating). Higher power reactors $(>100 \mathrm{MW})$ that operate continuously, for example commercial reactors, produce the greatest quantities of spent fuel. Lower power reactors (1-100 MW) that operate with relatively high capacity factors, such as material test reactors or isotope production reactors, can also generate significant quantities of spent fuel, but usually not on the scale of commercial reactors. Other low power reactors $(<1$ MW), such as neutron science research reactors or training reactors, which operate sporadically, tend to produce relatively small quantities of spent fuel and often keep their SNF in-core for added reactivity and safe storage.

Because spent fuel is produced from a variety of reactor types, the spent fuel inventories vary just as widely and even more so, since many reactors have stored inventories from past cores with different enrichments and fuel form. Although a survey and an assessment of spent fuel inventories worldwide is an extensive task, there are existing reactor fuel databases to assist in such assessments. For example, there are the PRIS [1], VISION [2], RRDB [13], and VISTA [4] databases; databases we have used for our survey here. This preliminary report attempts to address two tasks:

- Develop a survey of power reactor types worldwide in relation to SNF plutonium content and perform nuclear fuel calculations based on burnup. The reactor types were to be prioritized by plutonium content.

- Determine how many materials test reactors (MTRs) there are in the world, what type of fuel they use, and how much spent fuel they have in inventory.

The report is divided into two sections, one for each task. For both tasks, it is apparent that additional effort could provide substantially more detail beyond the limited scope of this preliminary assessment. 


\section{Power Reactor Survey}

The first task surveyed commercial power reactor types worldwide in relation to SNF and plutonium content. Fuel depletion calculations were performed and plutonium mass discharge rates developed along with plutonium isotopic masses for each commercial reactor type.

The PRIS database [1] was used to identify all of the operating commercial reactors around the world in 2011. Some assumptions were made, based on design similarities, in grouping of some of the identified commercial reactors. For example, VVERs (vodo-vodyanoi energetichesky reactors) also known as WWERs (water-water power reactors), a Russian pressurized water reactor design were placed in the PWR group, because these reactors are pressurized light water reactors. Canada deuterium uranium (CANDU) reactors make up the bulk of the PHWR group and although India's pressurized heavy water reactors have some design differences, they were placed naturally into the PHWR group. In addition, GCRs include both the single Magnox reactor with advanced gas-cooled reactors (AGRs) fleet in the United Kingdom (U.K.), as both Magnox and AGRs are gas-cooled, graphite-moderated reactors. Therefore, the 427 commercial reactors worldwide (Table 1) can be categorized into just five groups:

1. Pressurized Water Reactors (PWR)

2. Boiling Water Reactors (BWR)

3. Pressurized Heavy Water Reactor (PHWR)

4. Reaktory Bolshoi Moschchnosti Kanalny (RBMK)

5. Gas-Cooled Reactors (GCR).

Table 1 . Commercial reactors by type, country, and number.

\begin{tabular}{|l|l|l|l|l|l|}
\hline Country & PWR & BWR & PHWR & RBMK & GCR \\
\hline Argentina & & & 2 & & \\
\hline Armenia & 1 & & & & \\
\hline Belgium & 7 & & & & \\
\hline Brazil & 2 & & & & \\
\hline Bulgaria & 2 & & & & \\
\hline Canada & & & 18 & & \\
\hline China & 13 & & 2 & & \\
\hline Czech Republic & 6 & & & & \\
\hline Finland & 2 & 2 & & & \\
\hline France & 58 & & & & \\
\hline Germany & 7 & 2 & & & \\
\hline Hungary & 4 & & & & \\
\hline India & & 2 & 18 & & \\
\hline Iran & 1 & & & & \\
\hline Japan & 24 & 26 & & & \\
\hline Korea & 19 & & 4 & & \\
\hline Mexico & & 2 & & & \\
\hline Netherlands & 1 & & & & \\
\hline Pakistan & & & & \\
\hline Romania & & & & \\
\hline
\end{tabular}




\begin{tabular}{|l|l|l|l|l|l|}
\hline Country & PWR & BWR & PHWR & RBMK & GCR \\
\hline Russia & 17 & & & 15 & \\
\hline Slovakia & 4 & & & & \\
\hline Slovenia & 1 & & & & \\
\hline South Africa & 2 & & & & \\
\hline Spain & 6 & 2 & & & \\
\hline Sweden & 3 & 7 & & & \\
\hline Switzerland & 3 & 2 & & & \\
\hline Ukraine & 15 & & & & 15 \\
\hline United Kingdom & 1 & & & & \\
\hline United States of America & 69 & 35 & & & 15 \\
\hline TOTAL & 270 & 80 & 47 & & \\
\hline
\end{tabular}

It should be noted that there is a sixth commercial reactor type that could be added to our list, namely the fast reactor or fast breeder reactor. A single fast breeder reactor (FBR), the BN-600 in Russia, is operational and producing electricity today. However, with only a single location, we have chosen not to include this reactor type in this preliminary report.

Over the past 50 years, there have been a many evolutionary and design variants of the five identified reactor types above; reactors that were built, run, and produced saleable electricity. It is interesting and somewhat surprising that despite the large number of evolutionary and variant designs, commercial reactors worldwide have converged to just the five groups identified above.

Once we had grouped the reactor types, the next step was to acquire SNF burnup and reactor operating information for a typical reactor in each of the five commercial reactor groups and then to develop a simple burnup methodology that can use these burnup and reactor power data to estimate plutonium content in the SNF discharged and from this estimate plutonium production rates from this typical reactor. If we knew the burnup and power level for each of the 427 reactors listed in Table 1, a total worldwide plutonium production rate from commercial reactors could be estimated. This has not yet been done, due to the need to first find these data in the databases or published public domain literature. Another interesting task would be to develop a spatial database using a geographical information system to plot commercial reactors (and material test, research, and training reactors) on a world map and correlate plutonium production rates and current SNF inventories to each reactor site.

\subsection{Methodology}

An approximate methodology has been developed here specifically to estimate plutonium content in a spent fuel inventory from a commercial power reactor. The methodology needs very little input characterization data and uses characterization data that is usually readily available in the databases or in the public domain. For example, characterization information may include: reactor power, fuel burnup, initial loading, fuel residency time, fraction of core re-load, thermal efficiency, and capacity factor. In addition, the methodology requires end-of-cycle (EOC) isotopic mass fractions in order to estimate plutonium discharge rates. EOC isotopic mass fractions are, surprisingly, readily available for the five commercial power reactor types. Mass fraction data are also readily available for a variety of fuel burnups which then allows us to interpolate/extrapolate between these specific burnup data sets to generate approximate mass fractions at any burnup. These data are then sufficient to estimate plutonium mass content in discharged SNF, along with reactor power or reload plutonium production rates. The estimation methodology is described below in more detail. 
The estimation methodology developed for this task is straightforward and can be used effectively to obtain very reasonable spent fuel inventory estimates. The first step is to estimate the total initial heavy metal mass in the reactor core at beginning-of-cycle (BOC). There are a couple of paths to obtain the BOC initial heavy metal inventory depending on the available characterization data. Since our goal is to estimate the EOC heavy metal mass in the discharge fuel, which is unknown at this point, we assume that the total BOC heavy metal mass inventory is equal to the total EOC heavy metal mass. This mass equation is an approximation, but a very reasonable approximation especially for commercial power reactors, since the bulk of the low-enriched EOC fuel is still U-238. The total EOC heavy metal mass is then multiplied by the EOC isotopic mass fractions to obtain the uranium and plutonium isotopic masses in the discharge inventory. The approximation, using the BOC rather than the EOC heavy metal mass inventory, as mentioned, is quite accurate since the BOC and EOC heavy metal masses only differ by 2$3 \%$ for low-enrichment cores, such as in the commercial power reactors. The methodology is slightly conservative in that it then tends to over-predict the discharge isotopic masses.

It should be noted that the methodology can be refined later, if desired, to provide slightly more accurate estimates as follows. The EOC heavy metal mass can be re-estimated by subtracting the mass of depleted U-235 and U-238 from the BOC heavy metal mass inventory. The new EOC heavy metal mass can then be multiplied by the mass fractions to obtain new, more accurate discharge isotopic masses. This procedure can be iterated until the masses converge. For our purposes here, we simply equate the estimated total BOC to the EOC heavy metal mass with no iteration. Future work may add refinement.

To verify that the methodology is reasonable and to show how the methodology works, a benchmark problem is provided in Appendix A. This problem has been developed using a commercial PWR core and a $17 \times 17$ fuel rod assembly (Westinghouse design). Appendix A also includes two examples showing how the methodology can be applied with limited and different pieces of characterization data.

\subsubsection{Assumptions}

In order to estimate plutonium content of the SNF from the typical reactor in each reactor group, we made the following general assumptions in our analysis.

- A single typical average fuel burnup value is assumed for each typical reactor in each of the five commercial groups.

- Fuel burnup has a linear relationship with reactor power.

- A capacity factor of $90 \%$ is assumed for all reactors.

- Cycle times (fuel residency) for the five reactor types vary from approximately 1-4.5 years. Plutonium content and production rates are based on the reactor's typical cycle time and then scaled to 1-year or annual plutonium discharge rate in order to provide comparative basis.

- Reactor plant thermal efficiency is based on typical reported values for each reactor type.

\subsection{Results}

The reactor characterization information and calculated plutonium discharge rates are presented in this section by reactor type. Reactor and fuel parameters used in the estimation of isotopic plutonium discharge rates are briefly discussed along with details of the reactor core, assembly, rod, and fuel design.

\subsubsection{Pressurized Water Reactors (PWR)}

PWRs are the most widely used commercial reactor type in the world and represent approximately $63 \%$ of all commercial reactors worldwide. These reactors use pressurized light water $\left(\mathrm{H}_{2} \mathrm{O}\right)$ for both coolant and moderator. The fuel is comprised of cylindrical uranium dioxide $\left(\mathrm{UO}_{2}\right)$ pellets clad in a Zircaloy-4 tube which forms a fuel rod. Fuel rods are arranged into a square array of typcially $17 \times 17$ fuel rods which form an assembly. PWRs are typically refueled every 1.5 years, replacing $1 / 3$ of the core every cycle, which results in a fuel residence time of 54 months. PWR burnup has effectively doubled since early commercial usage, resulting in increases in enrichment [2]. Current limitations on burnup 
levels of PWR fuel are based on the potental for cladding degradation due to irradiation, oxidation, and hydrogenation. Relevant data for PWRs are shown in Table 2.

Table 2. Typical PWR characterization data [3] [4] [6].

\begin{tabular}{|l|l|}
\hline Fuel Type & $\mathrm{UO}_{2}$ \\
\hline Fuel Rod Diameter & $9.5 \mathrm{~mm}$ \\
\hline Fuel Rod Length & $3.66 \mathrm{~m}$ \\
\hline Cladding & $0.57 \mathrm{~mm}$ \\
\hline Fuel Pellet Diameter & $8.2 \mathrm{~mm}$ \\
\hline Fuel Pellet Length & $13.5 \mathrm{~mm}$ \\
\hline Active Fuel Length & $3.6 \mathrm{~m}$ \\
\hline Mass of $\mathrm{UO}_{2}$ in Core & $\sim 101 \mathrm{MT}$ \\
\hline Burnup & $45-50 \mathrm{MWd} / \mathrm{kgU}$ \\
\hline Enrichment & $4.0 \mathrm{wt} \% \mathrm{U}-235$ \\
\hline Fuel Assembly & $17 \times 17$ array \\
\hline
\end{tabular}

For the typical PWR representing the PWR commercial reactor group, we have assumed a core power of 1,000 MWe PWR, thermal efficiency of 33\%, capacity factor of $90 \%$, fuel residency time of 4.5 years, refuel cycle length of 1.5 years, and an average fuel burnup of $45 \mathrm{MWd} / \mathrm{kgU}$. EOL SNF mass fractions are given in Table 3 along with the calculated isotopic plutonium mass. The isotopic mass fractions in Table 3 are from the VISION database [2] and are in good agreement with data from the International Atomic Energy Agency Nuclear Fuel Cycle Simulation System (VISTA) [4] [8].

Table 3. PWR isotopic mass fractions and plutonium mass production rates.

\begin{tabular}{|c|c|c|c|c|}
\hline $\begin{array}{l}\text { Plutonium } \\
\text { Isotope }\end{array}$ & $\begin{array}{c}\text { Mass } \\
\text { Fraction }\end{array}$ & $\begin{array}{c}\text { Mass Produced } \\
\text { per } 1.5 \text { Years } \\
(\mathrm{kg})\end{array}$ & $\begin{array}{c}\text { Annual Mass } \\
\text { Production } \\
(\mathrm{kg})\end{array}$ & $\begin{array}{l}\text { Plutonium } \\
\text { Fraction } \\
(\%)\end{array}$ \\
\hline $\mathrm{Pu}-238$ & $2.3 \mathrm{E}-4$ & 6.9 & 4.6 & 2.1 \\
\hline $\mathrm{Pu}-239$ & $5.57 \mathrm{E}-3$ & 167.4 & 111.6 & 51.1 \\
\hline $\mathrm{Pu}-240$ & $2.73 \mathrm{E}-3$ & 82.0 & 54.7 & 25.1 \\
\hline $\mathrm{Pu}-241$ & $1.58 \mathrm{E}-3$ & 47.5 & 31.7 & 14.5 \\
\hline $\mathrm{Pu}-242$ & $7.8 \mathrm{E}-4$ & 23.4 & 15.6 & 7.2 \\
\hline $\mathrm{Pu}-244$ & $2.51 \mathrm{E}-8$ & $7.5 \mathrm{E}-4$ & $5.0 \mathrm{E}-4$ & 0.0 \\
\hline Total & & 327.2 & 218.2 & 100.0 \\
\hline
\end{tabular}

\subsubsection{Boiling Water Reactors (BWR)}

BWRs are the second most widely used commercial reactor type in the world and represent approximately $19 \%$ of all commercial reactors worldwide. These reactors use pressurized light water $\left(\mathrm{H}_{2} \mathrm{O}\right)$ and steam for both coolant and moderator. The fuel is comprised of cylindrical $\mathrm{UO}_{2}$ pellets clad in a Zircaloy-2 tube which forms a fuel rod. Fuel rods are arranged into a square array of typcially $8 \times 8$ fuel rods which form an assembly. BWRs, like PWRs, are typically refueled every 1.5 years, replacing $1 / 3$ of the core every cycle, which results in a fuel residence time of 54 months. BWR burnup, although typically slightly lower than PWRs, is still in the 45-50 MWd/kgU range [5]. BWR burnup has also effectively doubled since early commercial usage, resulting in increases in enrichment [2]. Relevant data for BWRs are shown in Table 4. 
Table 4. Typical BWR characterization data [2] [3] [5].

\begin{tabular}{|l|l|}
\hline Fuel Type & $\mathrm{UO}_{2}$ \\
\hline Fuel Rod Diameter & $12.27 \mathrm{~mm}$ \\
\hline Fuel Rod Length & $3.9 \mathrm{~m}$ \\
\hline Cladding & $0.813 \mathrm{~mm}$ Zircaloy-2 \\
\hline Fuel Pellet Diameter & $10.4 \mathrm{~mm}$ \\
\hline Fuel Pellet Length & $10.4 \mathrm{~mm}$ \\
\hline Active Fuel Length & $3.88 \mathrm{~m}$ \\
\hline Mass of $\mathrm{UO}_{2}$ in Core & $\sim 156 \mathrm{MT}$ \\
\hline Burnup & $45-50 \mathrm{MWd} / \mathrm{kgU}$ \\
\hline Enrichment & $4.0 \mathrm{wt} \% \mathrm{U}-235$ \\
\hline Fuel Assembly & $8 \times 8$ array \\
\hline
\end{tabular}

For the typical BWR representing the BWR commercial reactor group, we have assumed a core power of 1,000 MWe BWR, thermal efficiency of 33\%, capacity factor of $90 \%$, enrichment of $3.8 \%$, fuel residency time of 4.5 years, refuel cycle length of 1.5 years, and an average fuel burnup of $45 \mathrm{MWd} / \mathrm{kgU}$. EOL SNF mass fractions are given in Table 5 along with the calculated isotopic plutonium mass. The isotopic mass fractions in Table 5 are from the VISION database [2] and are in good agreement with data from VISTA [4] [8].

Table 5. BWR isotopic mass fractions and plutonium mass production rates.

\begin{tabular}{|c|c|c|c|c|}
\hline $\begin{array}{l}\text { Plutonium } \\
\text { Isotope }\end{array}$ & $\begin{array}{c}\text { Mass } \\
\text { Fraction } \\
\end{array}$ & $\begin{array}{c}\text { Mass Produced } \\
\text { per } 1.5 \text { Years } \\
(\mathrm{kg})\end{array}$ & $\begin{array}{l}\text { Annual Mass } \\
\text { Production } \\
(\mathrm{kg})\end{array}$ & $\begin{array}{l}\text { Plutonium } \\
\text { Fraction } \\
(\%) \\
\end{array}$ \\
\hline $\mathrm{Pu}-238$ & $1.98 \mathrm{E}-04$ & 6.6 & 4.4 & 2.3 \\
\hline $\mathrm{Pu}-239$ & $4.09 \mathrm{E}-03$ & 136.4 & 90.9 & 46.9 \\
\hline $\mathrm{Pu}-240$ & $2.54 \mathrm{E}-03$ & 84.7 & 54.5 & 29.1 \\
\hline $\mathrm{Pu}-241$ & $1.12 \mathrm{E}-03$ & 37.4 & 24.9 & 12.8 \\
\hline $\mathrm{Pu}-242$ & $7.79 \mathrm{E}-04$ & 26.0 & 17.3 & 8.9 \\
\hline $\mathrm{Pu}-244$ & $2.30 \mathrm{E}-08$ & 7.7E-4 & $5.1 \mathrm{E}-4$ & 0.0 \\
\hline Total & & 291.1 & 194.1 & 100.0 \\
\hline
\end{tabular}

\subsubsection{Pressurized Heavy Water Reactors (PHWR)}

PHWRs are the third most widely used commercial reactor type in the world and represent approximately $11 \%$ of all commercial reactors worldwide. The CANDU is the dominant PHWR design. These reactors use pressurized heavy water $\left(\mathrm{D}_{2} \mathrm{O}\right)$ for both coolant and moderator. The fuel is comprised of low-enriched cylindrical uranium dioxide $\left(\mathrm{UO}_{2}\right)$ pellets clad in a Zircaloy-4 tube which forms a fuel rod. CANDU-6 reactors typically consist of 380 fuel channels that are $6 \mathrm{~m}$ long and can hold 12 fuel assemblies [2] [4]. The fuel in the core is comprised of cylindrical fuel pellets inside fuel rods. A fuel bundle or assembly consists of 37 fuel rods arranged in three concentric rings about a single center rod. The inner ring consists of 6 rods, the middle 12 rods, and the outermost ring 18 fuel rods. The CANDU reactor has online refueling. The thermal efficiency for a 600 MWe CANDU-6 reactor is approximately 29.3\% [3]. Relevant data for PHWRs are shown in Table 6. 
Table 6. Typical PHWR characterization data [2] [3] [4].

\begin{tabular}{|l|l|}
\hline Fuel Type, typical & $\mathrm{UO}_{2}$ \\
\hline Fuel Rod Diameter & $13.1 \mathrm{~mm}$ \\
\hline Fuel Rod Length & $0.495 \mathrm{~m}$ \\
\hline Cladding & $0.42 \mathrm{~mm}$ Zircaloy-4 \\
\hline Fuel Pellet Diameter & $12.2 \mathrm{~mm}$ \\
\hline Fuel Pellet Length & $16.4 \mathrm{~mm}$ \\
\hline Active Fuel Length & $\mathrm{N} / \mathrm{A}$ \\
\hline Mass of $\mathrm{UO}_{2}$ in Core & $\sim 98.4 \mathrm{MT}$ \\
\hline Burnup & $7.0 \mathrm{MWd} / \mathrm{kgU}$ \\
\hline Enrichment & $0-1.7 \mathrm{wt} \% \mathrm{U}-235$ \\
\hline Fuel Assembly & 37 fuel rods in three concentric rings \\
\hline Fuel Assembly Length & $500 \mathrm{~mm}$ \\
\hline
\end{tabular}

The plutonium content in PHWR SNF is approximated by using the mass fractions provided in the VISTA report and the following assumptions: the fuel is naturally enriched and has an in-core residency time of 1 year, the PHWR is a 600 MWe plant with 29.3\% thermal efficiency, and the fuel has a 7 $\mathrm{MWd} / \mathrm{kgU}$ burnup.

For the typical PHWR representing the PHWR commercial reactor group, we have assumed a core power of 600 MWe PHWR, thermal efficiency of $29.3 \%$, capacity factor of $90 \%$, natural uranium enrichment of $0.7 \%$, fuel residency time of 1.0 years, and an average fuel burnup of $7.0 \mathrm{MWd} / \mathrm{kgU}$. For comparison purposes, since CANDU reactors refuel online and has a fuel residency time of 1 year, it is assumed that in 1.5 years the discharge mass is simply 1.5 times the annual discharge. EOL SNF mass fractions are given in Table 7 along with the calculated isotopic plutonium discharge rate. The isotopic mass fractions in Table 7 are from VISTA [4].

Table 7. PHWR isotopic mass fractions and plutonium mass production rates.

\begin{tabular}{|l|c|c|r|c|}
\hline $\begin{array}{c}\text { Plutonium } \\
\text { Isotope }\end{array}$ & $\begin{array}{c}\text { Mass } \\
\text { Fraction }\end{array}$ & $\begin{array}{c}\text { Mass Produced } \\
\text { per 1.5 Years } \\
(\mathrm{kg})\end{array}$ & $\begin{array}{c}\text { Annual Mass } \\
\text { Production } \\
(\mathrm{kg})\end{array}$ & $\begin{array}{c}\text { Plutonium } \\
\text { Fraction } \\
(\%)\end{array}$ \\
\hline $\mathrm{Pu}-238$ & $3.33 \mathrm{E}-06$ & 0.5 & 0.3 & 0.1 \\
\hline $\mathrm{Pu}-239$ & $2.66 \mathrm{E}-03$ & 380.4 & 253.6 & 69.2 \\
\hline $\mathrm{Pu}-240$ & $9.58 \mathrm{E}-04$ & 137.0 & 17.3 & 24.9 \\
\hline $\mathrm{Pu}-241$ & $1.81 \mathrm{E}-04$ & 25.9 & 3.7 & 1.0 \\
\hline $\mathrm{Pu}-242$ & $3.94 \mathrm{E}-05$ & 5.6 & - & 0 \\
\hline $\mathrm{Pu}-244$ & - & - & $\mathbf{3 6 6 . 3}$ & $\mathbf{1 0 0 . 0}$ \\
\hline \multicolumn{1}{|c|}{ Total } & & $\mathbf{5 4 9 . 4}$ & & \\
\hline
\end{tabular}

\subsubsection{Reaktory Bolshoi Moschchnosti Kanalny (RBMK)}

RBMKs are tied with GCRs as the fourth most widely used commercial reactor type in the world and represent approximately $3.5 \%$ of all commercial reactors worldwide. The RBMK is a Soviet-era reactor, also known as a pressure-tube graphite reactor (PTGR) and is graphite moderated and light-water-cooled. In addition to the reactor power generation capability, the reactor was also designed with the capability to breed plutonium. The RBMK-1000 uses graphite blocks containing 1693 zirconium alloy-lined fuel channels that house water-cooled fuel rods to produce steam for power production. The graphite blocks are cooled with an $80 / 20$ mixture of helium and nitrogen gas. The RMBK has excess reactivity that is 
controlled in the axial and radial directions by hundreds of control rods that regulate the power and shape the neutron flux throughout the reactor core, in addition to a mixture of burnable poison in the fuel.

The RBMK-1000 uses $\mathrm{UO}_{2}$ fuel intermixed with the burnable poison erbium oxide $\left(\mathrm{Er}_{2} \mathrm{O}_{3}\right)$ for reactivity control [5] [6]. An erbium oxide concentration of $0.41 \mathrm{wt} \%$ is typically used with $2.6 \mathrm{wt} \% \mathrm{U}$ 235 enrichment. The RBMK operates with online refueling. RBMK-1000 fuel assemblies consist of 18 fuel rods arranged in two concentric rings. The inner ring consists of 6 fuel rods and the outer ring 12 fuel rods. The RMBK-1000 has a thermal core power output of approximately $3200 \mathrm{MW}$ th and an electrical power output of 1,000 MWe. Relevant data for RBMKs are summarized in Table 8.

Table 8. Typical RBMK characterization data [4] [5] [6].

\begin{tabular}{|l|l|}
\hline Fuel Type & $\mathrm{UO}_{2}$ \\
\hline Fuel Rod Diameter & $13.6 \mathrm{~mm}$ \\
\hline Fuel Rod Length & $3.64 \mathrm{~m}$ \\
\hline Cladding & $0.85 \mathrm{~mm} \mathrm{Zr}-1 \% \mathrm{Nb}$ \\
\hline Fuel Pellet Diameter & $11.5 \mathrm{~mm}$ \\
\hline Fuel Pellet Length & $15 \mathrm{~mm}$ \\
\hline Active Fuel Length & $7 \mathrm{~m}(2 \times 3.43 \mathrm{~m})$ \\
\hline Mass of $\mathrm{UO}_{2}$ in Core & $\sim 218 \mathrm{MT}$ \\
\hline Burnup & $20 \mathrm{MWd} / \mathrm{kgU}$ \\
\hline Enrichment & $1.8-2.6 \mathrm{wt} \% \mathrm{U}-235$ \\
\hline Fuel Assembly & $18 \mathrm{fuel} \mathrm{rods} \mathrm{in} \mathrm{two} \mathrm{concentric} \mathrm{rings}$ \\
\hline Fuel Assembly Length & $10.014 \mathrm{~m}$ \\
\hline
\end{tabular}

An average RBMK-1000 fuel burnup is around $20 \mathrm{MWd} / \mathrm{kgU}$, depending on the fuel enrichment [3]. Typical residence time is on the order of 1,100 days [4]. These values are in reasonable agreement with assumptions made in the VISTA report that are used to approximate mass fractions of RBMK SNF. VISTA makes the following assumptions to calculate the mass fractions for RBMK SNF: $20 \mathrm{MWd} / \mathrm{kgU}$ burnup, 3-year in-core residency time, initial enrichment of 2.4\% U-235, and a capacity factor of $90 \%$. Since the RBMK is refueled online, it is assumed that since the fuel has a 3-year residency time, after 1.5 years, half of the core has been removed.

For the typical RBMK reactor representing the RBMK commercial reactor group, we have assumed a core power of 1,000 MWe, thermal efficiency of $31.25 \%$, capacity factor of $90 \%$, enrichment of $2.4 \%$, fuel residency time of 3.0 years, refuel cycle length of 1.5 years, and an average fuel burnup of 20 $\mathrm{MWd} / \mathrm{kgU}$. EOL SNF mass fractions are those given in Table 9 as calculated by VISTA [4].

Table 9. RBMK isotopic mass fractions and plutonium mass production rates.

\begin{tabular}{|c|c|c|c|c|}
\hline $\begin{array}{l}\text { Plutonium } \\
\text { Isotope }\end{array}$ & $\begin{array}{c}\text { Mass } \\
\text { Fraction } \\
\end{array}$ & $\begin{array}{c}\text { Mass Produced } \\
\text { per } 1.5 \text { Years } \\
(\mathrm{kg})\end{array}$ & $\begin{array}{c}\text { Annual Mass } \\
\text { Production } \\
(\mathrm{kg})\end{array}$ & $\begin{array}{l}\text { Plutonium } \\
\text { Fraction } \\
(\%) \\
\end{array}$ \\
\hline $\mathrm{Pu}-238$ & $2.26 \mathrm{E}-05$ & 1.8 & 1.2 & 0.5 \\
\hline $\mathrm{Pu}-239$ & $2.55 \mathrm{E}-03$ & 199.8 & 133.2 & 54.2 \\
\hline $\mathrm{Pu}-240$ & $1.55 \mathrm{E}-03$ & 121.5 & 81.0 & 32.9 \\
\hline $\mathrm{Pu}-241$ & $4.36 \mathrm{E}-04$ & 34.2 & 22.8 & 9.3 \\
\hline $\mathrm{Pu}-242$ & $1.50 \mathrm{E}-04$ & 11.7 & 7.8 & 3.2 \\
\hline $\mathrm{Pu}-244$ & - & - & 0.0 & 0 \\
\hline
\end{tabular}




\begin{tabular}{|l|l|l|l|l|}
\hline Total & & 369.0 & 246.0 & 100.0 \\
\hline
\end{tabular}

\subsubsection{Gas-Cooled Reactors (GCR)}

GCRs are tied with RBMKs as the fourth most widely used commercial reactor type in the world and represent approximately $3.5 \%$ of all commercial reactors worldwide. GCRs are graphite-moderated reactors that use natural uranium metal or uranium dioxide as fuel [11]. There are two well-known types of GCRs: (1) the Magnox reactor and (2) the advanced gas-cooled reactor (AGR). The Magnox reactor is essentially a large graphite pile cooled by $\mathrm{CO}_{2}$ gas. Capacity factors for these reactors were reported to be between 92-99\% [9]. The Calder Hall Magnox Generating Station produced $184 \mathrm{MWe}$ and had a thermal efficiency of $23 \%$. The core consisted of 1696 fuel channels; 6 fuel rods per channel [9]. The average in-core residency time for these reactors was approximately 1.0 years [4].

The AGR is the successor to the Magnox reactors in the U.K. There are 14 AGRs in operation today. The AGR is also graphite moderated and $\mathrm{CO}_{2}$ cooled; a thermal reactor with a thermal efficiency of approximately $40.7 \%$. A typical thermal power rating for these reactors is $1,623 \mathrm{MW}$ th, which produces approximately $660 \mathrm{MWe}$ [10]. AGRs have online refueling. The core consists of 332 fuel channels; 8 fuel rods per channel. The fuel rods are arranged with 3 concentric rings of fuel rods. The inner ring consists of 6 fuel rods, the middle ring 12 fuel rods, and the outer ring 18 fuel rods. Relevant data for GCRs are shown in Table 10.

Table 10. Typical GCR characterization data [4] [8] [9] [10] [11].

\begin{tabular}{|c|c|c|}
\hline & Magnox & AGR \\
\hline Fuel Type & U metal & $\mathrm{UO}_{2}$ \\
\hline Fuel Rod Diameter & $54 \mathrm{~mm}$ & $14.5 \mathrm{~mm}$ \\
\hline Fuel Rod Length & $1.016 \mathrm{~m}$ & $1.036 \mathrm{~m}$ \\
\hline Cladding & magnesium alloy & $0.38 \mathrm{~mm}$ stainless steel \\
\hline Fuel Pellet Diameter & $29.2 \mathrm{~mm}$ & $14.5 \mathrm{~mm}$ \\
\hline Fuel Pellet Length & N/A & N/A \\
\hline Active Fuel Length & N/A & $900 \mathrm{~mm}$ \\
\hline Mass of U Metal in Core & $120 \mathrm{MT}$ & $123 \mathrm{MT}$ \\
\hline Burnup & $5.6 \mathrm{MWd} / \mathrm{kgU}$ & $20 \mathrm{MWd} / \mathrm{kgU}$ \\
\hline Enrichment & Natural $0.7 \mathrm{wt} \% \mathrm{U}-235$ & $2.2-2.7 \mathrm{wt} \% \mathrm{U}-235$ \\
\hline Fuel Assembly & 1 cast metal bar & 36 rods, 3 concentric rings \\
\hline
\end{tabular}

For the typical GCR representing the GCR commercial reactor group, we have assumed a core power of 1,623 MWth, thermal efficiency of $40.7 \%$, capacity factor of $90 \%$, fuel residency time of 1.0 years, and an average fuel burnup of $20 \mathrm{MWd} / \mathrm{kgU}$. EOL SNF mass fractions are those given in Table 11 as calculated by VISTA [4].

Table 11. GCR isotopic mass fractions and plutonium mass production rates.

\begin{tabular}{|l|c|c|r|c|}
\hline $\begin{array}{c}\text { Plutonium } \\
\text { Isotope }\end{array}$ & $\begin{array}{c}\text { Mass } \\
\text { Fraction }\end{array}$ & $\begin{array}{c}\text { Mass Produced } \\
\text { per 1.5 Years } \\
(\mathrm{kg})\end{array}$ & $\begin{array}{c}\text { Annual Mass } \\
\text { Production } \\
(\mathrm{kg})\end{array}$ & $\begin{array}{c}\text { Plutonium } \\
\text { Fraction } \\
(\%)\end{array}$ \\
\hline $\mathrm{Pu}-238$ & $2.67 \mathrm{E}-05$ & 1.1 & 0.7 & 0.5 \\
\hline $\mathrm{Pu}-239$ & $2.77 \mathrm{E}-03$ & 110.0 & 73.3 & 53.8 \\
\hline $\mathrm{Pu}-240$ & $1.71 \mathrm{E}-03$ & 67.7 & 45.1 & 33.1 \\
\hline $\mathrm{Pu}-241$ & $4.55 \mathrm{E}-04$ & 18.0 & 5.1 & 8.8 \\
\hline $\mathrm{Pu}-242$ & $1.95 \mathrm{E}-04$ & 7.7 & 3.8 \\
\hline
\end{tabular}




\begin{tabular}{|c|c|c|r|c|}
\hline $\mathrm{Pu}-244$ & - & - & - & - \\
\hline Total & & $\mathbf{2 0 4 . 5}$ & 136.3 & $\mathbf{1 0 0 . 0}$ \\
\hline
\end{tabular}

\subsubsection{Conclusion}

Results from a preliminary survey of commercial nuclear reactors around the world reveal a total of 427 reactors producing electricity in 2011 . From these 427 reactors, five distinct types of commercial reactors emerge based primarily on moderator/coolant/fuel characteristics and core design. All are thermal reactors. Only one commercial fast reactor operates today and we have chosen to add this reactor and reactor type at a later date.

In our survey we have gathered both spent fuel and reactor core information on the five types of commercial power reactors. These data were then used in a simple methodology to estimate plutonium production rates based on refuel cycle times and then scaled to a 1-year or annual basis in order to compare plutonium production rates between the five reactor types. This also required us to select a typical reactor with typical operating and burnup characteristics which might be representative of the entire group. Several reactor databases were used to collect these data.

Plutonium mass production rates were then calculated based on the "typical" reactor for each reactor type. Table 12 lists the five commercial reactor types evaluated along with the fraction of the total commercial reactors each type represents, the typical reactor electric power output, the annual plutonium mass discharge rate, and the $\mathrm{Pu}-239$ weight fraction in the discharged plutonium mass or the spent fuel plutoniuim grade.

Table 12. Annual plutonium mass discharge rates by reactor type.

\begin{tabular}{|r|r|c|c|c|}
\hline \multicolumn{1}{|c|}{$\begin{array}{c}\text { Reactor } \\
\text { Type }\end{array}$} & $\begin{array}{c}\text { Fraction of } \\
\text { Commerical } \\
\text { Reactors (\%) }\end{array}$ & $\begin{array}{c}\text { Core Power } \\
\text { Electric } \\
\text { (MWe) }\end{array}$ & $\begin{array}{c}\text { Annual Pu } \\
\text { Discharge } \\
(\mathrm{kg})\end{array}$ & $\begin{array}{c}\text { Plutonium Grade } \\
\text { Pu-239 Content } \\
(\mathrm{wt} \%)\end{array}$ \\
\hline PHWR & 11.0 & 600 & 366.3 & 69.2 \\
\hline RBMK & 3.5 & 1000 & 246.0 & 54.2 \\
\hline PWR & 63.0 & 1000 & 218.2 & 51.1 \\
\hline BWR & 19.0 & 1000 & 194.1 & 46.9 \\
\hline GCR & 3.5 & 660 & 136.3 & 53.8 \\
\hline
\end{tabular}

Based on our calculated results, the PHWR produces and discharges substantially more plutonium than the other four reactor types. This is probably due primarily to the softer neutron spectrum in the PHWR, but fuel residency time and core power also likely contribute. The PHWR also has the highest $\mathrm{Pu}-239$ content in the spent fuel discharge, or an incredible $70 \% \mathrm{Pu}-239$, and nearly $75 \%$ combining the two fissile isotopes $\mathrm{Pu}-239$ and $\mathrm{Pu}-241$. RBMKs would be second in plutonium mass discharge rate, followed by PWRs, BWRs, and GCRs.

More detailed depletion analyses could be performed to verify the plutonium mass fractions we extracted from the databases and the calculated plutonium discharge rates using our simple methodology. Higher fidelity depletion calculation results could also identify key reactor and burnup parameters that could have significant impact on plutonium discharge rates for these five reactor types. 


\section{Materials Test Reactor Survey}

The second task surveyed research reactors to determine how many materials test reactors (MTRs) there are in the world, what type of fuel they use, and how much spent fuel they have in inventory.

Our MTR survey used the IAEA Research Reactor Database [13] and discovered a total of 703 research reactors worldwide. The list of research reactors includes MTRs, isotope production reactors, neutron science research reactors, and training reactors, both operational and shutdown. For this initial survey, we selected those reactors with core powers greater than 1.0 MW. The database produced 106 research reactors designated as operational, in temporary shutdown, or under construction. All 106 reactors are listed in Appendix B.

MTRs are typically designed to test reactor fuels and materials, but many produce industrial and medical radio-isotopes. MTRs can operate over a wide power range (0.1-250 MW) and sustain relatively high capacity factors (20-70\%). Thus, high-power, high-capacity factor MTRs have the potential to produce and accumulate significant quantities of SNF. A few notable high-power MTRs include:

250 MW Advanced Test Reactor (ATR) - Idaho National Laboratory, USA,

85 MW High Flux Isotope Reactor (HFIR) - Oak Ridge National Laboratory, USA,

50 MW Belgium Reactor-2 (BR2), Mol, Belgium,

50 MW Japan Material Testing Reactor (JMTR), Japan,

45 MW High Flux Reactor (HFR), Petten, Netherlands,

25 MW Halden Boiling Water Reactor, (HBWR), Halden, Norway,

20 MW South African Fundamental Atomic Reactor Installation (SAFARI-1), Pelindaba, South

Africa,

10 MW Light Water Reactor-15 (LVR-15), Czech Republic,

10 MW Budapest Research Reactor (BRR), Budapest, Hungary, and

5 MW Argentine Reactor-3 (RA-3), Argentina.

Several of these MTRs use high-enriched uranium (HEU) fuel, and because of the high initial enrichment these MTRs will not produce significant quantities of plutonium. However, because all highenriched SNF has the potential to remain high-enriched ( $>20 \mathrm{wt} \% \mathrm{U}-235)$ even after discharge, SNF from these reactors always remains a potential security risk. Since most MTRs worldwide are going to lowenriched uranium (LEU) fuel, high-power, high-capacity factor MTRs will now begin to produce significant quantities of reactor-grade plutonium.

Many of the 106 research reactors on our list operate at either relatively low continuous power or in pulsed mode. These reactors can have a variety of different applications which include:

- Neutron scattering experiments,

- Neutron radiography,

- Neutron activation analysis [17].

Research reactors due to their relatively low power and sporadic operation accumulate relatively low burnup and therefore produce relatively lower quantities of SNF. Most research reactors simply keep their reactivity-expended fuel rods or elements in-core, moved to the core periphery or stored in racks on the periphery of the reactor tank. Here the spent fuel rods/elements remain indefinitely and thus pose only a minimal risk due to theft [17]. The level of risk increases for high-enriched fuel. Typically these reactors have relatively small SNF inventories.

\subsection{Methodology}

Information on research reactor SNF fuel inventories is limited. The IAEA collects information from research reactors around the world using questionnaires sent to IAEA member states through a representative at each reactor site and through a network of representatives at the reactor sites. This 
information is collected and uploaded into the IAEA Research Reactor Database (RRDB) [13]. SNF information that is collected is loaded into another database, access to which is controlled and generally not publicly available.

For this task, the RRDB was used as our primary source of information. Research reactors (106) with $\geq 1 \mathrm{MW}$ core power ratings were identified and characterization information on each of these reactors was extracted, which included: reactor location, fuel type, thermal power level, flux intensity, and reactor usage/application. Information on spent fuel inventories was only available in summary form.

\subsubsection{Assumptions}

The main assumptions for this study were core power ratings of $\geq 1.0 \mathrm{MW}$ and a reactor status corresponding to (1) operational, (2) under construction, or (3) temporarily shutdown condition. Permanently shutdown reactors were not included although follow-on work may include these reactors in order to status the associated SNF inventories.

\subsection{Results}

Results of this study are given in the extensive data table of Appendix B. The 106 research reactors identified are located in 41 different countries, the majority of which are in the United States, Russia, and China. A variety of fuel types are used, the most prevalent being $\mathrm{UO}_{2}, \mathrm{U}_{3} \mathrm{O}_{8}$, and $\mathrm{U}_{3} \mathrm{Si}_{2}$ (uranium silicide). Of the 106 research reactors, 48 are material test reactors, 78 have the capability to perform neutron experiments, and 77 produce medical and industrial radio-isotopes. Future work on Appendix B will fill in the burnup and enrichment column data.

Access to the spent fuel inventories of the 106 research reactors was not possible due to access limitations and time constraints. However, the following cumulative SNF element/assembly data shows the status of fuel elements/assemblies associated with research reactors around the world [13]:

- 61,048 fuel assemblies in storage

- 24,268 fuel assemblies in-core

- 44,015 in industrialized countries

- 17,033 in developing countries

- 20,630 HEU assemblies

- 40,418 LEU assemblies.

The majority of spent fuel assemblies currently in-storage are stored securely in industrialized countries. The IAEA data shows that the United States typically supplied enriched fuel for reactors in North America and in the Asia-Pacific region. Russia supplied most of the enriched fuel in Eastern Europe. It is interesting to note that HEU outweighs LEU in North America, whereas the reverse is true in Western Europe. It is also worth noting that a significant fraction of Russian-origin HEU was originally enriched to approximately $40 \%$ as compared with United States-origin HEU which was originally enriched to $90 \%$ or more, according to IAEA reports [14] [16].

Appendix $\mathrm{C}$ shows the relative number and distribution of research reactor spent nuclear fuel assemblies from U.S., Russian, or other sources by global region. Table C-1 shows where research reactor spent fuel assemblies are located by region, according to their U-235 enrichment. Specific information on exact numbers of fuel assemblies and where they are stored exist in some cases, but the information is considered sensitive and is not publicly available. The most specific information found is shown in Appendix D. These data represent actual spent fuel inventory data available in early 1993 and projected production for the following ten years for aluminum-based and TRIGA fuel assemblies of U.S. origin. It estimates that 106 research reactors in 41 countries will have an inventory of approximately 22,700 irradiated aluminum-based and TRIGA fuel assemblies initially containing about $19,200 \mathrm{~kg}$ of enriched uranium as of January 2006. 
For SNF inventory, half of the operational research reactors are actually less than $100 \mathrm{~kW}$ and will operate with a lifetime core, resulting in no spent fuel generation at least until these reactors are permanently shut down. Research reactors present special challenges in the back-end of the fuel cycle because many different reactor designs using a large variety of fuel types have been built, often for special purposes. These include the management of experimental and exotic fuels with no reprocessing route, and a significant number of fuel assemblies that failed in their reactors, or were subsequently corroded in wet storage [15].

\subsubsection{Conclusion}

Based on our survey, some general conclusions can be drawn. There are more research reactors (703) than commercial reactors (427) worldwide. The larger number of research reactors and their multipurpose applications require and use a large variety fuel types, element/assembly geometries, core power ratings, and operating modes. Hence, the SNF inventories generated by these reactors will vary in quantity and plutonium content, dependent primarily on the fuel enrichment and energy output (MWd). With proper permissions and granting of higher levels of access to restricted reactor database information, more detailed information related to reactor enrichment, burnup, and stored SNF inventories can potentially be obtained from IAEA and other sources.

Again as with the commercial reactors, an interesting future task would be to develop a spatial database using a geographical information system to plot material test, research, and training reactors on a world map and correlate stored SNF inventories and SNF generation rates to each reactor site. 


\section{References}

1. International Atomic Energy Agency, 2012, Nuclear Power Reactors in the World, Reference Data Series 2, Vienna, Austria, IAEA-RDS-2/32, June 2012.

2. Idaho National Laboratory VISION Database, Transmutation Data Library, accessed September 2012 .

3. Todreas, N.E., and M.S. Kazimi, 1990, Nuclear Systems: Volume 1-Thermal Hydraulic Fundamentals, Hemisphere Publishing Corporation, New York.

4. International Atomic Energy Agency, 2007, Nuclear Fuel Cycle Simulation System (VISTA), IAEATECDOC-1535, February 2007.

5. Horsten, M., W. Belcher, 2001, "Fracture Toughness and Tensile Properties of Irradiated Reactor Pressure Vessel Cladding Material," Effects of Radiation on Materials: $20^{\text {th }}$ International Symposium, ASTM STP 1405-EB, DOI: 10.1520/STP1405-EB.

6. Siegmann, E., 2000, Initial Cladding Condition, Office of Civilian Radioactive Waste Management Analysis, ANL-EBS-MD-000048, Rev 00, Argonne National Laboratory.

7. Murphy, B., 2006, ORIGEN-ARP Cross-Section Libraries for the RBMK-1000 System, ORNL/TM2006/139, Oak Ridge National Laboratory, November 2006.

8. Allan, C., K. Dormuth, 1999, The Back End of the Fuel Cycle and CANDU, IAEA-SM-357/10, International Atomic Energy Agency.

9. Lamarsh, J., Baratta, A., 2001, Introduction to Nuclear Engineering, Third Edition, Prentice-Hall, Upper Saddle River, NJ.

10. United Kingdom Nirex Limited, 2002, Radionuclide Content for a Range of Irradiated Fuels, Document Number Pcdocs395337v5 Rev2, Electrowatt-Ekono.

11. Nonbøl, E., 1996, Description of the Advanced Gas Cooled Type of Reactor (AGR), NKS/RAK2(96)TR-C2, Riso National Laboratory, Roksilde, Denmark.

12. International Atomic Energy Agency, 2010, Research Reactors: Purpose and Future, November 2010 .

13. International Atomic Energy Agency Research Reactor Database (RRDB), accessed September 2012, http://nucleus.iaea.org/RRDB/Reports/CategoryList.aspx

14. Adelfang, P., A.J. Soares, and I. N. Goldman, 2007, "Spent Nuclear Fuel from Research Reactors: International Status and Perspectives, World Status of Research Reactor Spent Fuel" in Safety Related Issues of Spent Nuclear Fuel Storage (Springer Netherlands, 2007), pp. 3-27.

15. Ritchie, I.G., P.C. Ernest, 1999, "Research Reactor Spent Fuel Status," Research Reactor Utilization, Safety and Management Symposium, Lisbon Portugal, September 6-10, 1999, IAEA-SM-360/3.

16. Ritchie I.G., Growing Dimensions, http://www.iaea.org/Publications/Magazines/Bulletin/Bull401/article7.html, visited September 2012.

17. U.S. Nuclear Regulatory Commission, Backgrounder on Research and Test Reactors, http://www.nrc.gov/reading-rm/doc-collections/fact-sheets/research-reactors-bg.html, published August 2011, visited September 2012. 


\section{Appendix A \\ Methodology to Estimate EOC Reactor Isotopic Plutonium Discharge Mass}

\section{Benchmark Problem}

The assumed commercial power reactor for the benchmark problem here is an older Westinghouse pressurized water reactor (PWR) with 17x17 fuel assemblies. The following data is assumed to be given:

(1) Core power:

$1,150 \mathrm{MWe}$

(2) Thermal efficiency:

$33.7 \%$

(3) Burnup:

33,000 MWd/MTU

(4) No. of assemblies:

193 assemblies/core

(5) No. of fuel rods:

264 rods/assembly

(6) BOC uranium:

$1,769.11 \mathrm{~g} / \mathrm{rod}$

(7) Core fraction re-load:

$50 \%$

(8) Capacity factor: $\quad 80 \%$

(9) Fuel residence time: 3 years

From these data the initial or BOC total heavy metal core loading can be estimated as follows:

$$
(1,769.11) \mathrm{gU} / \mathrm{rod} *(264) \mathrm{rods} / \text { assembly } *(193) \text { assemblies/core }=\underline{90.140 \mathrm{MTU}}
$$

The BOC total heavy metal core loading can also be estimated starting with the fuel discharge burnup as follows:

$$
\begin{aligned}
& \text { (1 MTU/33,000 MW } \left.{ }_{t h} \mathrm{D}\right) *\left(1.0 \mathrm{MW} W_{t h} / 0.337 \mathrm{MW} W_{e} *(1,150) \mathrm{MW} / \text { core } *(365.25)\right. \text { days/year * } \\
& \text { (3.0) fuel residence time } *(0.80) \text { capacity factor }=90.647 \underline{\mathrm{MTU}}
\end{aligned}
$$

The two ways of calculating the BOC total heavy metal uranium core loading are in good agreement.

The next step involves the EOC isotopic mass fractions. Typically, these mass fractions must be derived from detailed depletion calculations, but for our methodology we would simply use the mass fractions from the open literature for a specific reactor and fuel burnup. The mass fractions [MF] used in the benchmark problem here and the mass fractions values that follow are actually calculated from a detailed depletion calculation using a fuel burnup of 35,000 MWd/MTU for the Westinghouse PWR reactor. The total EOC heavy metal mass is calculated from the detailed depletion calculation to be 86.914 MT. Note the slight difference in burnups between the detailed depletion calculation $(35,000$ $\mathrm{MWd} / \mathrm{MTU})$ and the Westinghouse PWR specifications listed above (33,000 MWd/MTU). The difference is small and should not be a significant concern.

Selected EOC isotopic mass fractions derived from the detailed depletion calculation:

$$
\begin{aligned}
& {[\mathrm{MF}]^{\mathrm{U} 235}=0.0088285} \\
& {[\mathrm{MF}]^{\mathrm{U} 238}=0.9743000} \\
& {[\mathrm{MF}]^{\text {Pu239 }}=0.0067884} \\
& {[\mathrm{MF}]^{\text {Pu240 }}=0.0023648} \\
& {[\mathrm{MF}]^{\text {Pu241 }}=0.0013425} \\
& {[\mathrm{MF}]^{\text {Pu242 }}=0.0006108}
\end{aligned}
$$

Discharge EOC isotopic mass inventory estimates: 
I. For the detailed depletion calculation:

(Core fraction re-load) $*[M F] *($ EOC total heavy metal core loading $)=$ Discharge mass inventory

$$
\begin{aligned}
& (0.50) *[\mathrm{MF}]]^{\mathrm{U} 235} *(86.814) \mathrm{MTU}=0.3837 \mathrm{MT} \mathrm{U}-235 \\
& (0.50) *[\mathrm{MF}]^{\mathrm{U} 238} *(86.914) \mathrm{MTU}=42.340 \mathrm{MT} \mathrm{U}-238 \\
& (0.50) *[\mathrm{MF}]^{\mathrm{Pu} 239} *(86.914) \mathrm{MTU}=0.2950 \mathrm{MT} \mathrm{Pu}-239 \\
& (0.50) *[\mathrm{MF}]^{\mathrm{Pu} 240} *(86.914) \mathrm{MTU}=0.1028 \mathrm{MT} \mathrm{Pu}-240 \\
& (0.50) *[\mathrm{MF}]^{\mathrm{Pu} 241} *(86.914) \mathrm{MTU}=0.0583 \mathrm{MT} \mathrm{Pu}-241 \\
& (0.50) *[\mathrm{MF}]^{\mathrm{Pu} 242} *(86.914) \mathrm{MTU}=0.0265 \mathrm{MT} \mathrm{Pu}-242
\end{aligned}
$$

II. For the present developed methodology:

(Core fraction re-load) $*[M F] *(B O C$ total heavy metal core loading $)=$ Discharge mass inventory

$$
\begin{aligned}
& (0.50) *[\mathrm{MF}]^{\mathrm{U} 235} *(90.14) \mathrm{MTU} \quad=0.3979 \mathrm{MT} \mathrm{U}-235 \\
& (0.50) *[\mathrm{MF}]^{\mathrm{U} 238} *(90.14) \mathrm{MTU} \quad=43.9117 \mathrm{MT} \mathrm{U}-238 \\
& (0.50) *[\mathrm{MF}]^{\mathrm{Pu} 239} *(90.14) \mathrm{MTU} \quad=0.3060 \mathrm{MT} \mathrm{Pu}-239 \\
& (0.50) *[\mathrm{MF}]^{\mathrm{Pu} 240} *(90.14) \mathrm{MTU} \quad=0.1066 \mathrm{MT} \mathrm{Pu}-240 \\
& (0.50) *[\mathrm{MF}]^{\mathrm{Pu} 241} *(90.14) \mathrm{MTU} \quad=0.0605 \mathrm{MT} \mathrm{Pu}-241 \\
& (0.50) *[\mathrm{MF}]^{\mathrm{Pu} 242} *(90.14) \mathrm{MTU} \quad=0.0275 \mathrm{MT} \mathrm{Pu}-242
\end{aligned}
$$

Comparing cases I and II above, it is apparent that our methodology (Case II) here does indeed produce very reasonable and slightly conservative discharge inventory estimates relative to the much more sophisticated depletion calculation for this commercial Westinghouse PWR.

In addition to the benchmark problem above verifying that our methodology is accurate, two additional PWR examples are given here to show how given minimal characterization data for a commercial reactor, characterization data acquired in the public domain, can be used to estimate burnup discharge isotopic mass inventories. The first example uses three pieces of characterization data and the second example just two along with the EOC mass fractions. The point is that the two examples utilize different and minimal information to still produce accurate $\mathrm{Pu}-239$ discharge mass at re-load.

\section{EXAMPLE \#1:}

$\begin{array}{lll}\text { Given: } & \text { Fuel Burnup: } & 45,000 \mathrm{MWd} / \mathrm{MTU} \\ \text { Given: } & \text { Core Power: } & 1,000 \mathrm{MWe} \\ \text { Given: } & \text { Fuel Residence Time: } & 4.5 \text { years }\end{array}$

Analysis:

$\left(1 \mathrm{MTU} / 45,000 \mathrm{MW_{th }} \mathrm{D}\right) *\left(1.0 \mathrm{MW} \mathrm{W}_{t h} / 0.37 \mathrm{MW_{e }}\right) *(1,000) \mathrm{MW_{e }} /$ core $*(365.25)$ days/year * (4.5) fuel residence time $*(0.90)$ capacity factor $=88.845 \underline{\mathrm{MTU}}$

Analysis:

$$
(1 / 3) *[M F]^{P u 239} * 88.845 M T U=(1 / 3) *(0.00513) *(88.845)=\underline{0.152 M T P u-239} \text { (discharge at }
$$
re-load)

Assumption: $[\mathrm{MF}]^{\mathrm{Pu} 239}=0.00513$ (found in public domain)

Assumption: Core Re-load $=1 / 3$ (found in public domain or typical of PWR)

Assumption: Capacity Factor $=90 \%$ (found in public domain or typical of PWR) 
EXAMPLE \#2:

$\begin{array}{lll}\text { Given: } & \text { Fuel Burnup: } & 45,000 \mathrm{MWd} / \mathrm{MTU} \\ \text { Given: } & \text { BOC } \mathrm{UO}_{2} \text { Loading: } & 102 \mathrm{MT}\end{array}$

Analysis: (102) $\mathrm{MT} \mathrm{UO}_{2} *$ (0.88) mass U/mass $\mathrm{UO}_{2}=89.76 \mathrm{MTU}$ (initial BOC heavy metal uranium)

Analysis: $\quad(1 / 3) *[M F]^{P u 239} * 89.76 M T U=(1 / 3) *(0.00513) *(89.76)=\underline{0.153 M T P u-239}$ (discharge at re-load)

Assumption: $[\mathrm{MF}]^{\mathrm{Pu} 239}=0.00513$ (found in public domain)

Assumption: Core Re-load = 1/3 (found in public domain or typical of PWR)

Other simple examples can be derived from these two examples for different given pieces of information. 


\section{Appendix B \\ High Power Research Reactors with Materials Test Capabilities}

Appendix B contains information for the 106 research reactors that are listed in the IAEA Research Reactor Database for research reactors with core power ratings $\geq 1.0 \mathrm{MW}$. The spreadsheet information includes: reactor type, fuel type, enrichment, fuel origin, clad material, reflector/coolant/moderator material, and reactor application. 
B-2 


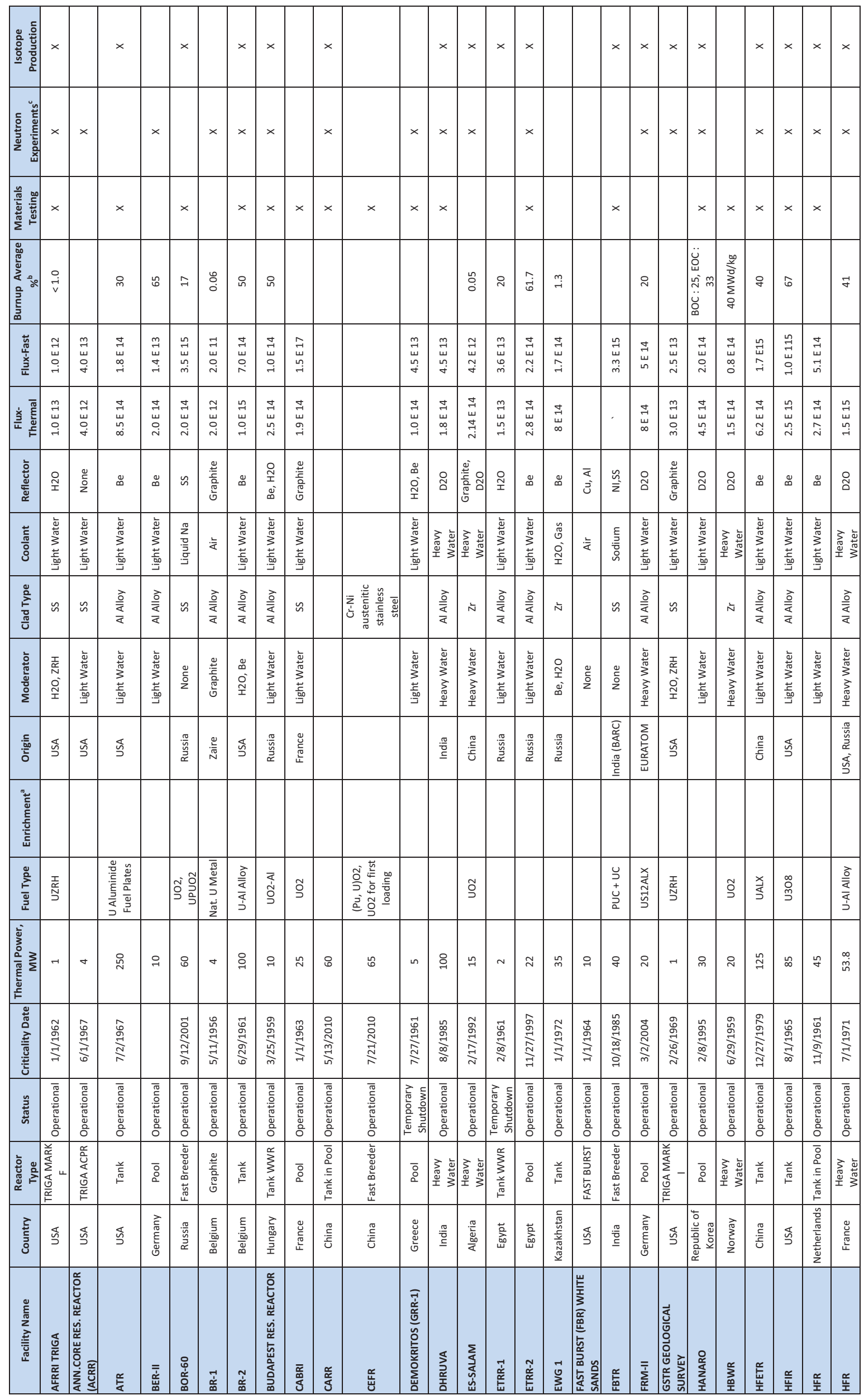




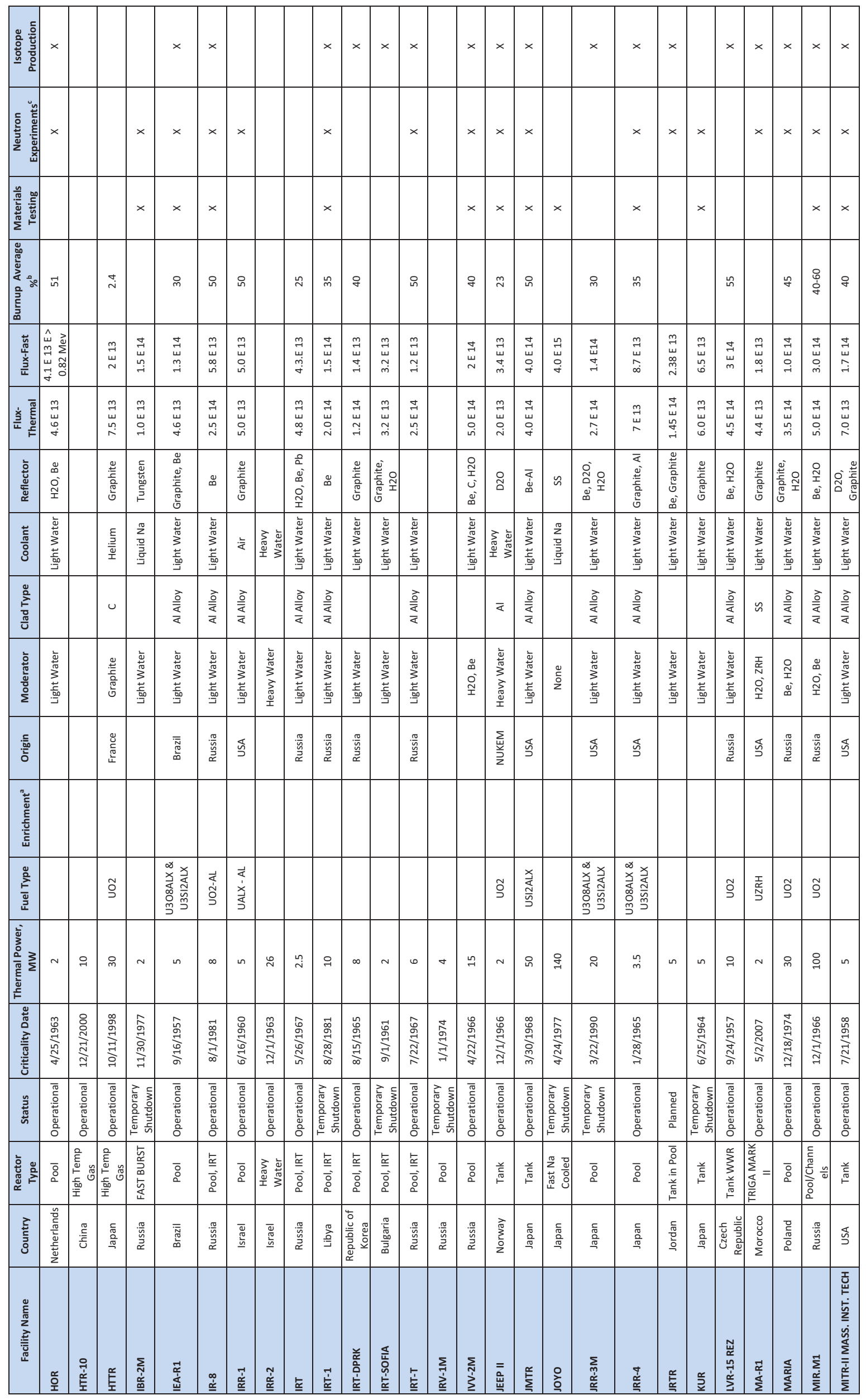




\begin{tabular}{|c|c|c|c|c|c|c|c|c|c|c|c|c|c|c|c|c|c|c|c|c|c|c|c|c|c|c|}
\hline 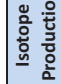 & $\times$ & $\times$ & $\times$ & & & $\times$ & $\times$ & $\times$ & $x$ & $\times$ & $\times$ & $\times$ & $\times$ & $\times$ & $\times$ & & & $x$ & $\times$ & $x$ & $\times$ & $\times$ & $\times$ & $\times$ & $\times$ & $\times$ \\
\hline 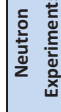 & & $x$ & $\times$ & $x$ & & $\times$ & $\times$ & $x$ & $x$ & $\times$ & $\times$ & $\times$ & $\times$ & $\times$ & $\times$ & & $x$ & $x$ & & $x$ & & $\times$ & $x$ & $x$ & $\times$ & $x$ \\
\hline 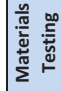 & & & & & & $x$ & $\times$ & & & & $\times$ & & & $\times$ & $\times$ & & & $\times$ & $\times$ & $x$ & $\times$ & $\times$ & $x$ & & & \\
\hline 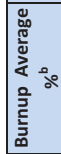 & タ & 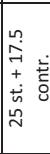 & 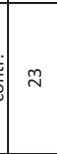 & ? & 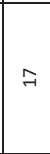 & & & & & 品 & 8 & & & $\stackrel{\sim}{\circ}$ & & & in & $\stackrel{\infty}{\sim}$ & $F$ & 7 & & $\approx$ & $\vec{N}$ & 黛 & $\stackrel{\infty}{\sim}$ & \\
\hline 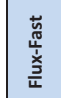 & 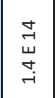 & $\begin{array}{l}\stackrel{m}{\sharp} \\
\stackrel{a}{\sigma}\end{array}$ & 志 & $\underset{\sim}{\stackrel{J}{\sim}}$ & 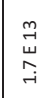 & \begin{tabular}{|l|}
$\vec{J}$ \\
$\vec{\sim}$ \\
$\stackrel{H}{*}$
\end{tabular} & $\begin{array}{l}\vec{Z} \\
\vec{w} \\
\dot{i}\end{array}$ & $\begin{array}{l}\approx \\
\tilde{u} \\
\dot{q} \\
\dot{q}\end{array}$ & 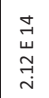 & \begin{tabular}{|l}
$\vec{J}$ \\
$\vec{w}$ \\
$\dot{m}$ \\
$\dot{m}$
\end{tabular} & 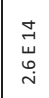 & $\underset{\sim}{\stackrel{m}{\sharp}}$ & 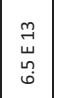 & 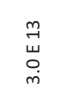 & $\underset{\stackrel{\leftrightarrow}{\breve{r}}}{\stackrel{\Xi}{u}}$ & 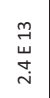 & $\underset{\sim}{\sim}$ & $\underset{\substack{\vec{u} \\
\sim}}{\stackrel{J}{N}}$ & 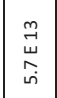 & 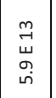 & $\underset{\sim}{\stackrel{\mathscr{H}}{\rightleftarrows}}$ & \begin{tabular}{|c|}
0 \\
$\stackrel{m}{u}$ \\
$\omega$ \\
$\omega$
\end{tabular} & 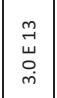 & \begin{tabular}{|l|}
$\vec{J}$ \\
$\vec{\sim}$ \\
$\stackrel{\sim}{*}$
\end{tabular} & 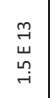 & 氶 \\
\hline 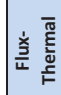 & \begin{tabular}{|c|}
$m$ \\
$\stackrel{n}{u}$ \\
0 \\
$\infty$
\end{tabular} & 志 & 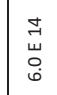 & $\mid \begin{array}{l}\vec{J} \\
\stackrel{\vec{a}}{\sigma} \\
\dot{\sigma}\end{array}$ & 䍃 & \begin{tabular}{|l}
$\vec{J}$ \\
$\vec{\omega}$ \\
$\dot{\sigma}$
\end{tabular} & \begin{tabular}{|l}
$\stackrel{m}{u}$ \\
$\stackrel{\sim}{\sim}$
\end{tabular} & 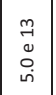 & 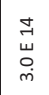 & 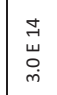 & 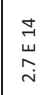 & $\mid \begin{array}{l}m \\
\stackrel{m}{W} \\
\stackrel{i}{i}\end{array}$ & 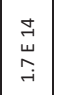 & 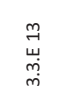 & $\begin{array}{l}\stackrel{a}{\sharp} \\
\stackrel{u}{\sigma}\end{array}$ & 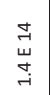 & $\underset{⿱}{\stackrel{m}{Z}}$ & $\underset{\substack{m \\
\infty}}{\stackrel{m}{u}}$ & 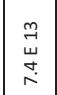 & 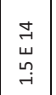 & 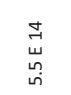 & 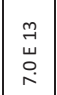 & \begin{tabular}{|l|}
$\stackrel{m}{u}$ \\
$\stackrel{\sim}{\sim}$ \\
\end{tabular} & \begin{tabular}{|l|}
\multirow{J}{\pm}{} \\
$\underset{ت}{ \pm}$ \\
\end{tabular} & 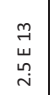 & $\underset{\sim}{\stackrel{\vec{N}}{\sim}}$ \\
\hline 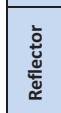 & $\Xi$ & 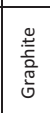 & 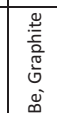 & ฉి & 六 & 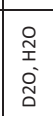 & 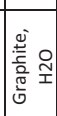 & $\mid$ & ปั & $\stackrel{\text { O̊ }}{0}$ & ळ & 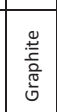 & 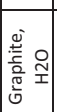 & 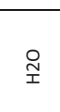 & ฉั & 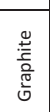 & 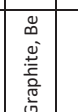 & 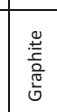 & 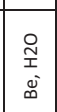 & $\stackrel{\circ}{\text { Iิ }}$ & ळ & $\approx$ & 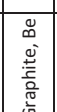 & 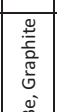 & 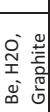 & 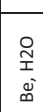 \\
\hline 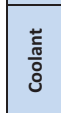 & 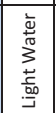 & 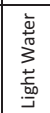 & 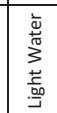 & 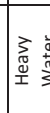 & 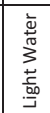 & 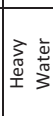 & 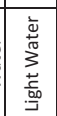 & 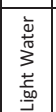 & 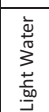 & 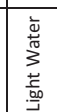 & 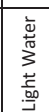 & 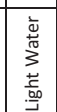 & 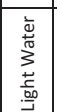 & 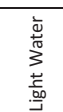 & 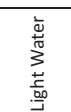 & 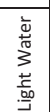 & 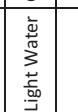 & 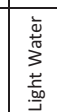 & 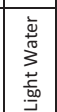 & 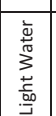 & 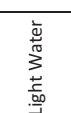 & 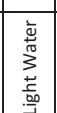 & 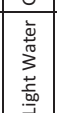 & 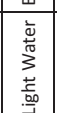 & 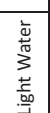 & 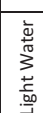 \\
\hline 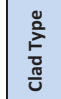 & $\frac{\overrightarrow{\frac{\partial}{\bar{q}}}}{\mathrm{q}}$ & $\frac{\partial}{\overline{\frac{\partial}{\pi}}}$ & $\frac{\bar{\partial}}{\bar{z}}$ & $\mid \frac{\frac{\partial}{4}}{4}$ & $\stackrel{\&}{N}$ & & $\approx$ & \begin{tabular}{|l|}
$\frac{\bar{z}}{\bar{q}}$ \\
$\frac{4}{4}$
\end{tabular} & $\vec{\varangle}$ & & $\varangle$ & 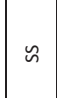 & \begin{tabular}{|l|}
$\frac{3}{\bar{q}}$ \\
$\frac{\pi}{4}$
\end{tabular} & 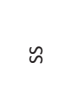 & 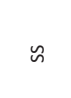 & 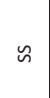 & $\frac{\text { o }}{\overline{\frac{3}{4}}}$ & 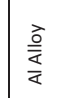 & 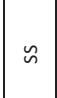 & $\approx$ & & $\frac{\text { 高 }}{\frac{\bar{z}}{4}}$ & 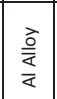 & 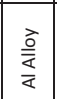 & 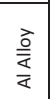 & \\
\hline 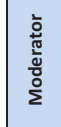 & 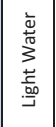 & 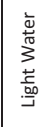 & 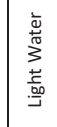 & 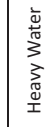 & 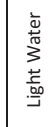 & 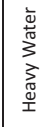 & 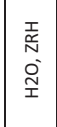 & 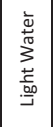 & 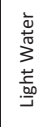 & 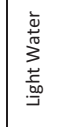 & 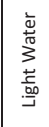 & 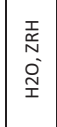 & 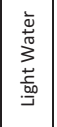 & 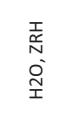 & 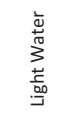 & 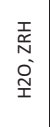 & 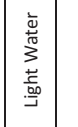 & 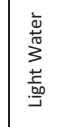 & 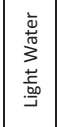 & 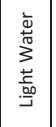 & 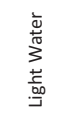 & 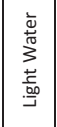 & 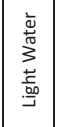 & 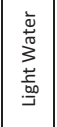 & 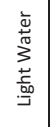 & 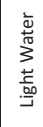 \\
\hline 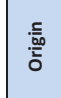 & 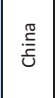 & 岁 & 离 & 药 & 苞 & & 至 & 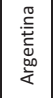 & & 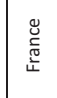 & 岁 & 离 & 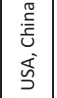 & 崩 & 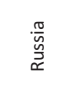 & 䔅 & 离 & 离 & 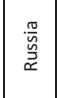 & 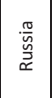 & & 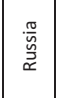 & \begin{tabular}{|l|} 
\\
S
\end{tabular} & 离 & 离 & \\
\hline 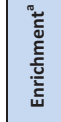 & & & & & & & & & & & & & & & & & & & & & & & & & & \\
\hline 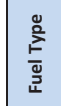 & & 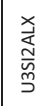 & 宏 & 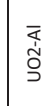 & & & 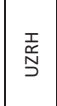 & & 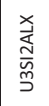 & & 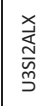 & 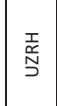 & 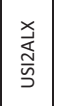 & & ᄋ̃ & & รั & \begin{tabular}{|l}
$\bar{\alpha}$ \\
$\tilde{\tilde{I}}$
\end{tabular} & ऽั & ऽั & & \begin{tabular}{|l|}
$\vec{L}$ \\
$\dot{d}$ \\
$\dot{d}$ \\
$\vec{J}$ \\
\end{tabular} & 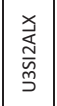 & 号 & 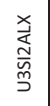 & \\
\hline 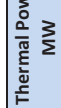 & n & $m$ & 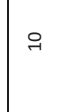 & i & n & 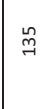 & -7 & 4 & i & $\exists$ & \% & $\overrightarrow{7}$ & 욤 & $\rightarrow$ & $\stackrel{-}{\circ}$ & $\rightarrow$ & $\rightarrow$ & 악 & $\wedge$ & 0 & : & in & $\sim$ & 욱 & $\rightarrow$ & 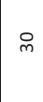 \\
\hline 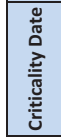 & 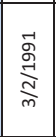 & 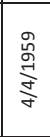 & 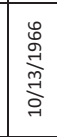 & 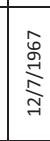 & 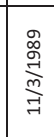 & 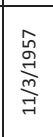 & 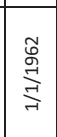 & 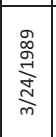 & 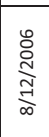 & 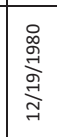 & 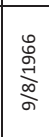 & 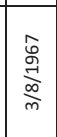 & 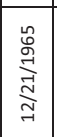 & 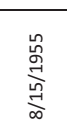 & 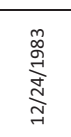 & $\begin{array}{l}\stackrel{8}{\circ} \\
\stackrel{2}{7} \\
\stackrel{\infty}{2}\end{array}$ & 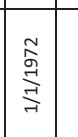 & 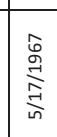 & 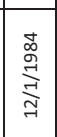 & 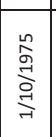 & & 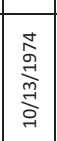 & 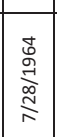 & 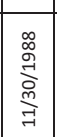 & 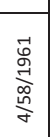 & 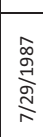 \\
\hline 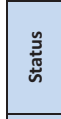 & 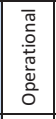 & 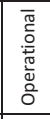 & 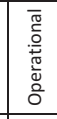 & 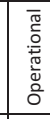 & 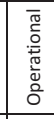 & 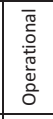 & 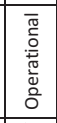 & 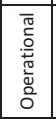 & 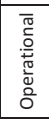 & 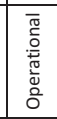 & 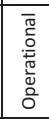 & 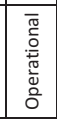 & 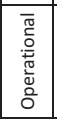 & 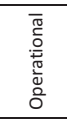 & 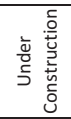 & 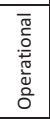 & 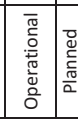 & 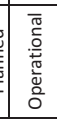 & 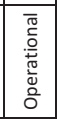 & 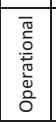 & 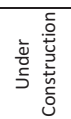 & 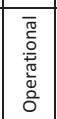 & 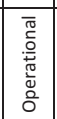 & 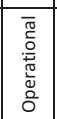 & 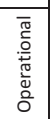 & 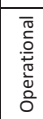 \\
\hline 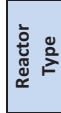 & $\overline{\mathrm{o}}$ & 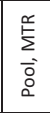 & 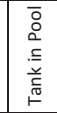 & & & & 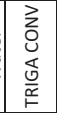 & 흠 & 흥 & $\bar{\circ}$ & $\overline{0}$ & 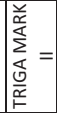 & $\overline{\mathrm{o}}$ & 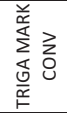 & 总 & 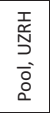 & 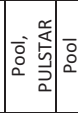 & $\bar{s}$ & \begin{tabular}{|l|}
$\bar{o}$ \\
\end{tabular} & $\overline{0}$ & 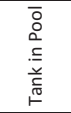 & \begin{tabular}{|l|} 
\\
\end{tabular} & \begin{tabular}{|l|}
$\bar{o}$ \\
\end{tabular} & 흠 & $\bar{\circ}$ & 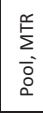 \\
\hline 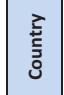 & 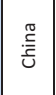 & \begin{tabular}{|l} 
\\
0 \\
0 \\
0 \\
$\tilde{E}$ \\
0
\end{tabular} & 离 & 崩 & 莺 & 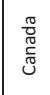 & 至 & 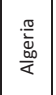 & 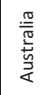 & 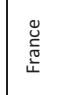 & \begin{tabular}{|l}
$\stackrel{8}{0}$ \\
$\frac{\tilde{E}}{5}$
\end{tabular} & 离 & 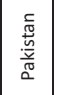 & 崩 & 离 & 疍 & 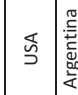 & 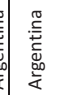 & 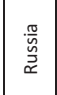 & 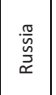 & 总 & 苛 & 芯 & 产 & 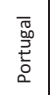 & 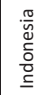 \\
\hline 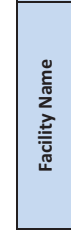 & \begin{tabular}{|l|}
$\frac{x}{\Sigma}$ \\
\end{tabular} & 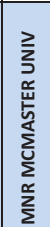 & 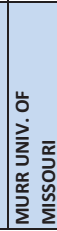 & 諺 & 定 & $\overrightarrow{\frac{\partial}{z}}$ & 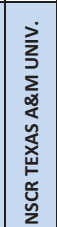 & $\frac{\alpha}{z}$ & ò & 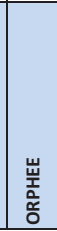 & 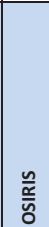 & 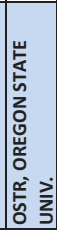 & 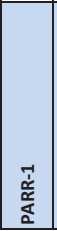 & 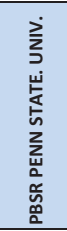 & 兰 & $\begin{array}{l}\frac{0}{2} \\
\frac{\underline{y}}{a} \\
\frac{3}{\alpha}\end{array}$ & 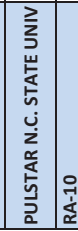 & & 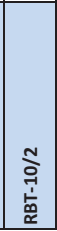 & 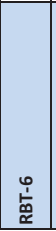 & 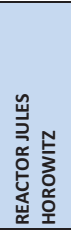 & \begin{tabular}{|l|}
$\vec{I}$ \\
壱 \\
\end{tabular} & 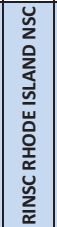 & $\stackrel{9}{\dot{1}}$ & $\overline{\bar{\alpha}}$ & \begin{tabular}{|l} 
and \\
d.
\end{tabular} \\
\hline
\end{tabular}




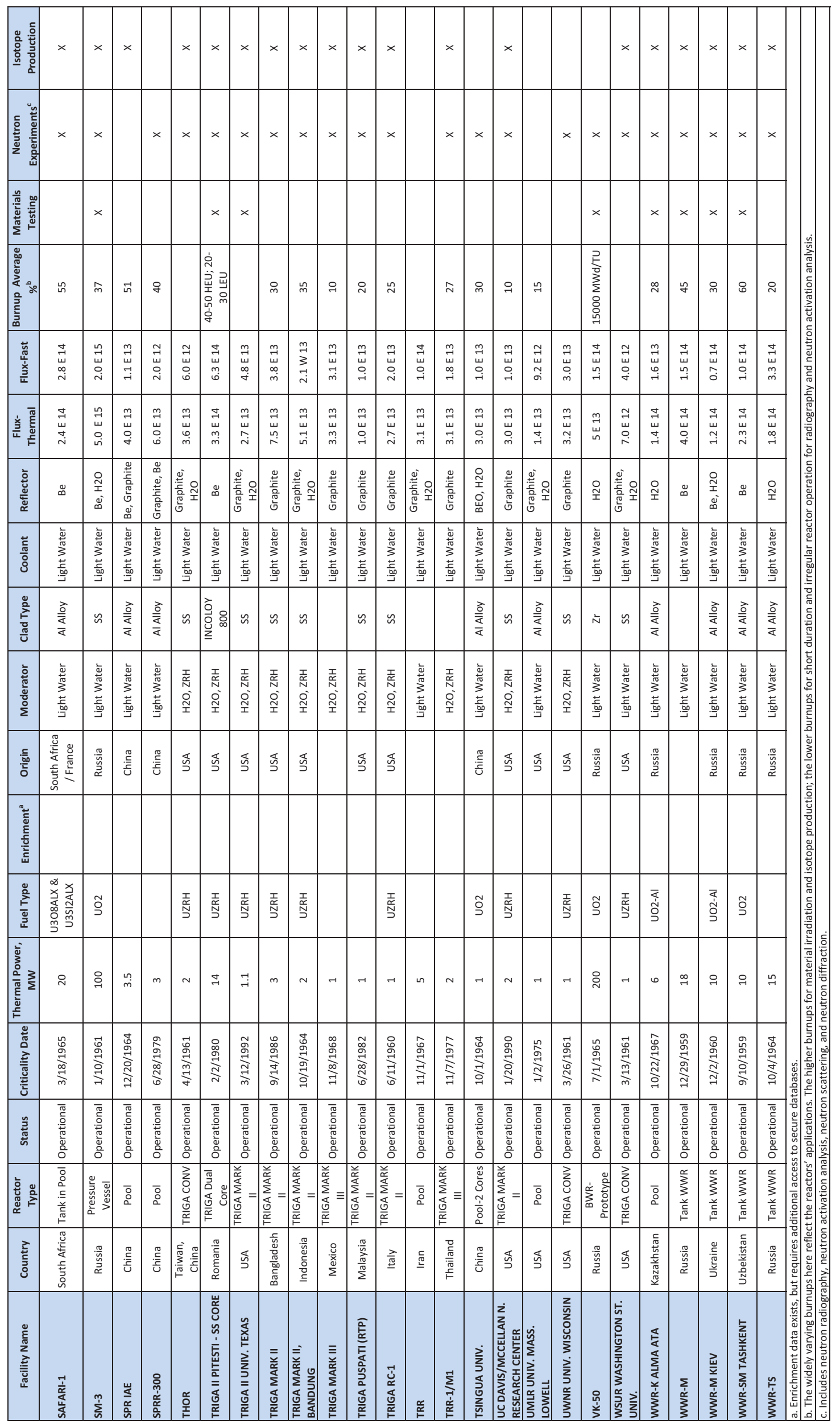




\section{Appendix C \\ Distribution of Research Reactor Spent Fuel by Origin, Region, Enrichment and Number of Assemblies}

Appendix $\mathrm{C}$ gives the number and distribution of research reactor spent nuclear fuel elements/assemblies from U.S., Russian or other sources by global region. In addition, Table C-1 shows where research reactor spent fuel assemblies are located by region and uranium enrichment.

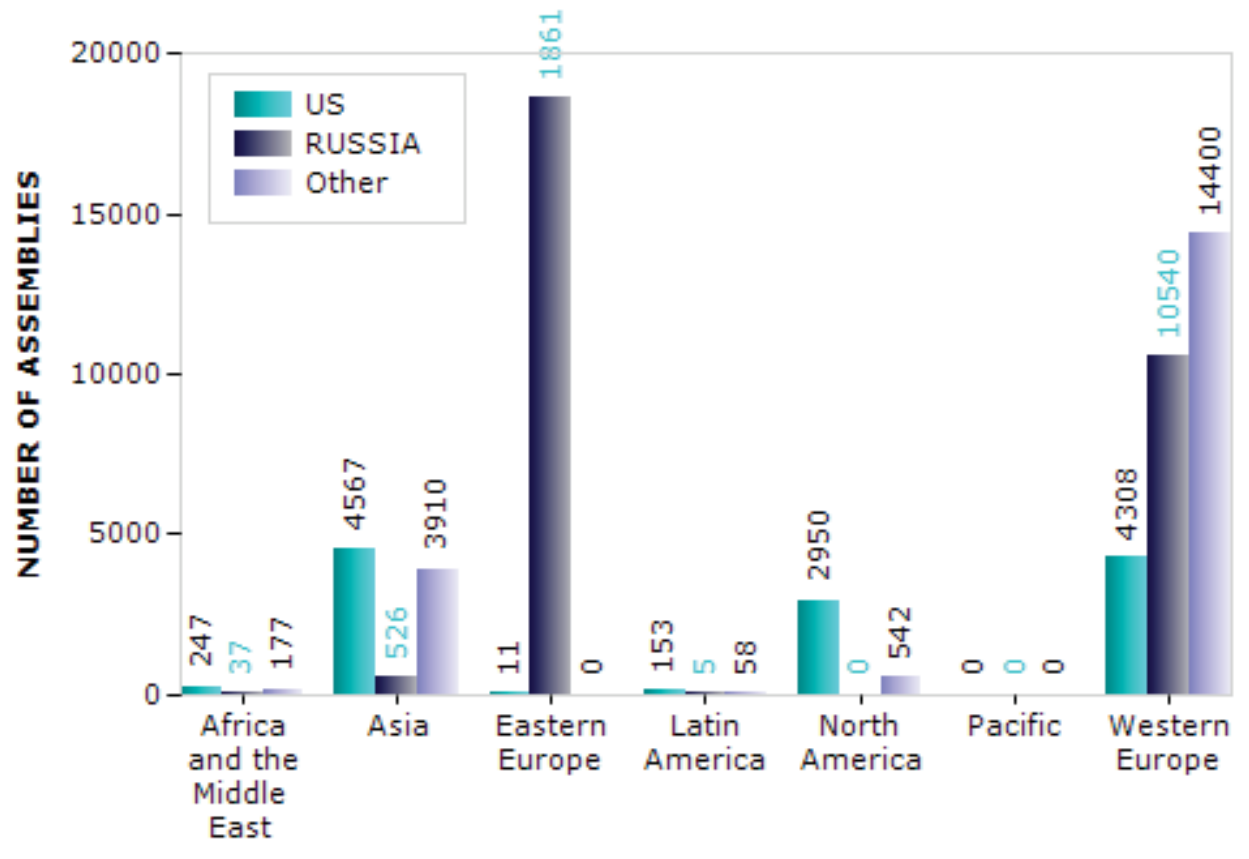

REGION

Table C-1. Research reactor distribution by region, enrichment, and number of assemblies.

\begin{tabular}{|l|l|l|}
\hline Region & $\begin{array}{l}\text { Enrichment } \\
(\mathrm{wt} \% \text { U-235) }\end{array}$ & $\begin{array}{l}\text { No. of Assemblies in } \\
\text { storage }\end{array}$ \\
\hline $\begin{array}{l}\text { Africa and } \\
\text { the } \\
\text { Middle } \\
\text { East }\end{array}$ & 10 & 37 \\
\cline { 2 - 3 } & 19.9 & 58 \\
\cline { 2 - 3 } & 45 & 177 \\
\cline { 2 - 3 } & 93 & 189 \\
\cline { 2 - 3 } & Subtotal & $\mathbf{4 6 1}$ \\
\hline Asia & 0 & 662 \\
\cline { 2 - 3 } & 0.2 & 225 \\
\cline { 2 - 3 } & 0.7 & 22 \\
\cline { 2 - 3 } & 1.5 & 345 \\
\cline { 2 - 3 } & 1.9 & 131 \\
\cline { 2 - 3 } & 2 & 441 \\
\cline { 2 - 3 } & 2.3 & 20 \\
\cline { 2 - 3 } & 3 & 308 \\
\hline
\end{tabular}

\begin{tabular}{|l|l|l|}
\hline Region & $\begin{array}{l}\text { Enrichment } \\
(w t \% \text { U-235) }\end{array}$ & $\begin{array}{l}\text { No. of Assemblies in } \\
\text { storage }\end{array}$ \\
\hline \multirow{4}{*}{} & 10 & 887 \\
\cline { 2 - 3 } & 18 & 288 \\
\cline { 2 - 3 } & 19.7 & 417 \\
\cline { 2 - 3 } & 19.8 & 1,266 \\
\cline { 2 - 3 } & 19.9 & 481 \\
\cline { 2 - 3 } 20 & 18 \\
\cline { 2 - 3 } & 23 & 122 \\
\cline { 2 - 3 } & 36 & 383 \\
\cline { 2 - 3 } & 45 & 66 \\
\cline { 2 - 3 } & 46 & 112 \\
\cline { 2 - 3 } & 60 & 89 \\
\cline { 2 - 3 } & 70 & 850 \\
\cline { 2 - 3 } & 80 & \\
\hline
\end{tabular}




\begin{tabular}{|c|c|c|}
\hline Region & $\begin{array}{l}\text { Enrichment } \\
\text { (wt\% U-235) }\end{array}$ & $\begin{array}{l}\text { No. of Assemblies in } \\
\text { storage }\end{array}$ \\
\hline & 90 & 1037 \\
\hline & 93 & 146 \\
\hline & Subtotal & 9,003 \\
\hline \multirow{17}{*}{$\begin{array}{l}\text { Eastern } \\
\text { Europe }\end{array}$} & 2 & 6,692 \\
\hline & 3.6 & 2 \\
\hline & 4.4 & 13 \\
\hline & 5 & 100 \\
\hline & 6 & 68 \\
\hline & 10 & 1,019 \\
\hline & 19.7 & 2 \\
\hline & 19.9 & 3 \\
\hline & 36 & 4,765 \\
\hline & 36.5 & 23 \\
\hline & 36.6 & 87 \\
\hline & 45 & 106 \\
\hline & 80 & 1,180 \\
\hline & 89.3 & 20 \\
\hline & 90 & 4,537 \\
\hline & 93 & 11 \\
\hline & Subtotal & 18,628 \\
\hline \multirow{7}{*}{$\begin{array}{l}\text { Latin } \\
\text { America }\end{array}$} & 19.7 & 5 \\
\hline & 19.8 & 13 \\
\hline & 19.9 & 113 \\
\hline & 20.1 & 18 \\
\hline & 80 & 22 \\
\hline & 90 & 45 \\
\hline & Subtotal & 216 \\
\hline \multirow{10}{*}{$\begin{array}{l}\text { North } \\
\text { America }\end{array}$} & 0.7 & 542 \\
\hline & 6 & 40 \\
\hline & 18 & 18 \\
\hline & 18.3 & 263 \\
\hline & 19.5 & 9 \\
\hline & 19.7 & 114 \\
\hline & 19.8 & 635 \\
\hline & 19.9 & 257 \\
\hline & 69 & 7 \\
\hline & 70 & 151 \\
\hline
\end{tabular}

\begin{tabular}{|c|c|c|}
\hline Region & $\begin{array}{l}\text { Enrichment } \\
\text { (wt\% U-235) }\end{array}$ & $\begin{array}{l}\text { No. of Assemblies in } \\
\text { storage }\end{array}$ \\
\hline & 90 & 28 \\
\hline & 93 & 1,331 \\
\hline & 93.1 & 7 \\
\hline & 93.2 & 90 \\
\hline & Subtotal & 3,492 \\
\hline Pacific & Subtotal & 0 \\
\hline \multirow{27}{*}{$\begin{array}{l}\text { Western } \\
\text { Europe }\end{array}$} & 0.7 & 19,089 \\
\hline & 1.5 & 308 \\
\hline & 2.2 & 210 \\
\hline & 3.5 & 73 \\
\hline & 5 & 3 \\
\hline & 7.5 & 813 \\
\hline & 8.8 & 180 \\
\hline & 9.5 & 35 \\
\hline & 10 & 1,120 \\
\hline & 19 & 52 \\
\hline & 19.5 & 3 \\
\hline & 19.7 & 34 \\
\hline & 19.8 & 537 \\
\hline & 19.9 & 2,442 \\
\hline & 20 & 5 \\
\hline & 36 & 2,112 \\
\hline & 37.5 & 77 \\
\hline & 44.5 & 5 \\
\hline & 45 & 51 \\
\hline & 50 & 1 \\
\hline & 80 & 121 \\
\hline & 85 & 43 \\
\hline & 89.8 & 1 \\
\hline & 90 & 34 \\
\hline & 93 & 1,875 \\
\hline & 93.1 & 24 \\
\hline & Subtotal & 29,248 \\
\hline & Total & 61,048 \\
\hline
\end{tabular}




\section{Appendix D \\ Estimates of Aluminum-Based and TRIGA Irradiated Fuel Inventories - U.S. Origin}

Appendix D represents actual spent fuel inventory data available in early 1993 and projected production for the following ten years. It estimates that 104 research reactors in 41 countries will have an inventory of approximately 22,700 irradiated aluminum-based and TRIGA fuel assemblies initially containing about $19,200 \mathrm{~kg}$ of enriched uranium of United States Origin as of January 2006. Inventory reported is not based on fuel assemblies.

Table D-1. Estimates of Irradiated Fuel Inventories of Foreign and Research and Test Reactors using Aluminum-based and TRIGA Fuels Containing Uranium of USA origin as of 2001.

\begin{tabular}{|c|c|c|c|c|}
\hline Country & $\begin{array}{l}\text { HEU Spent Fuel } \\
\text { Inventories - } \\
\text { Number }\end{array}$ & $\begin{array}{l}\text { HEU Spent Fuel } \\
\text { Weight }(\mathrm{kg})\end{array}$ & $\begin{array}{l}\text { LEU Spent Fuel } \\
\text { Inventories - } \\
\text { Number }\end{array}$ & $\begin{array}{l}\text { LEU Spent Fuel } \\
\text { Weight (kg) }\end{array}$ \\
\hline Argentina & 238 & 49.4 & 0 & 0 \\
\hline Belgium & 1359 & 554.8 & 0 & 0 \\
\hline Brazil & 43 & 7.5 & 48 & 37.2 \\
\hline Canada & 1222 & 617.3 & 889 & 2208 \\
\hline Chile & 58 & 11.9 & 0 & 0 \\
\hline France & 763 & 831.7 & 486 & 1189 \\
\hline Germany & 900 & 184.7 & 104 & 156.7 \\
\hline Greece & 154 & 27.1 & 12 & 12.3 \\
\hline Indonesia & 0 & 0 & 90 & 107.2 \\
\hline Iran & 29 & 0 & 0 & 0 \\
\hline Israel & 127 & 27.8 & 0 & 0 \\
\hline Italy & 117 & 21.4 & 33 & 21.7 \\
\hline Japan & 1420 & 717.5 & 833 & 1355.4 \\
\hline Netherlands & 993 & 403.5 & 68 & 143.8 \\
\hline Pakistan & 82 & 15.9 & 0 & 0 \\
\hline Peru & 0 & 0 & 0 & 0 \\
\hline Portugal & 2 & .3 & 50 & 40.1 \\
\hline South Africa & 50 & 9.8 & 0 & 0 \\
\hline South Korea & 0 & 0 & 70 & 133.6 \\
\hline Taiwan & 69 & 9.7 & 58 & 56.7 \\
\hline Thailand & 31 & 5.3 & 0 & 0 \\
\hline
\end{tabular}

* Data compiled from "Foreign Research Reactor Irradiated Nuclear Fuel Inventories Containing HEU and LEU of United States Origin," ANL/RERTR/TM-22, pp. 22-23, J. E. Matos. 